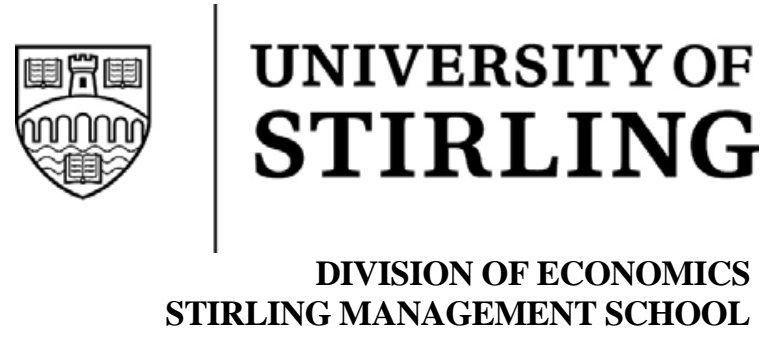

\title{
Offshoring and the \\ Onshore Composition of Tasks and Skills
}

Sascha O. Becker

Karolina Ekholm

Marc-Andreas Muendler

Stirling Economics Discussion Paper 2009-18

August 2009

Online at http://www.economics.stir.ac.uk 


\title{
Offshoring and the Onshore Composition of Tasks and Skills*
}

\author{
Sascha O. Becker \\ Karolina Ekholm \\ Stirling University, Ifo, CESifo and IZA \\ Sveriges Riksbank, CEPR and CESifo \\ Marc-Andreas Muendler \\ UC San Diego, CESifo, and NBER
}

\begin{abstract}
We analyze the relationship between offshoring and the onshore workforce composition in German multinational enterprises (MNEs), using plant data that allow us to discern tasks, occupations, and workforce skills. Offshoring is associated with a statistically significant shift towards more non-routine and more interactive tasks, and with a shift towards highly educated workers. Moreover, the shift towards highly educated workers is in excess of what is implied by changes in either the task or the occupational composition. Whether offshored activities are located in low-income or high-income countries does not alter the direction of the relationship. We find offshoring to predict between 10 and 15 percent of observed changes in wage-bill shares of highly educated workers and measures of non-routine and interactive tasks.
\end{abstract}

Keywords: Trade in tasks; multinational enterprises; demand for labor; linked employer-employee data

JEL Classification: F16, F14, F23, J23, J24

\footnotetext{
${ }^{*}$ We thank Costas Arkolakis, Beata Javorcik, Anselm Mattes, Andrés Rodriguez-Clare and Deborah Swenson for insightful comments. Alexandra Spitz-Oener generously contributed task classifications for robustness checks. We thank Heinz Herrmann, Alexander Lipponer, Beatrix Stejskal-Passler, and Elisabetta Fiorentino at Deutsche Bundesbank for support with firm data, and Stefan Bender, Iris Koch and Stephan Heuke at the Bundesagentur für Arbeit for assistance with plant records. Karin Herbst and Thomas Wenger at Deutsche Bundesbank kindly shared string-matching expertise. Ming Zeng provided excellent research assistance. We gratefully acknowledge financial support from the VolkswagenStiftung, the European Commission's Seventh Research Framework (contract number 225551) and the Ifo Institute. Becker also thanks the Fritz-Thyssen-Stiftung for financial support, while Ekholm thanks the Wallander Foundation and the Swedish Council for Working Life and Social Research. Muendler gratefully acknowledges the hospitality of Princeton University while this research was completed.

『karolina.ekholm@riksbank.se, corresponding, Ph: +46 (0)8787 01 16. The views expressed in this paper do not necessarily reflect those of the Riksbank.
} 


\section{Introduction}

There is considerable agreement among economists that fragmentation of production, and offshoring of production stages, likely affects employment and wages across countries. However, there is disagreement as to the direction of these effects. If offshoring mainly involves tasks carried out by low-skilled labor, the relative demand for low-skilled labor would decline, contributing to a widening wage gap between skilled and unskilled labor (Feenstra and Hanson 1996, 1999). Since offshoring is likely to be associated with cost reductions, which put downward pressure on wages, low-skilled workers may nevertheless benefit from an increase in their real wages. However, if the associated cost reductions are particularly strong in industries employing low-skilled labor intensively, offshoring might actually reduce the wage gap between skilled and unskilled labor as resources are reallocated towards lowskill intensive industries in general equilibrium (Jones and Kierzkowski 1990, Grossman and Rossi-Hansberg 2008). ${ }^{1}$

Recently, several authors have argued that the nature of performed tasks may be more relevant for a job's propensity to be offshored than the skill level of the worker (see e.g. Leamer and Storper 2001, Markusen 2006, Jensen and Kletzer 2006, Blinder 2006). This is of particular importance for labor-market consequences if offshoring involves relatively many tasks that high-skilled workers carry out so that low-skilled workers are perhaps less affected. Interpreting computer-tomography images or X-rays, for instance, typically requires education at the upper-secondary or tertiary level, but can easily move offshore. ${ }^{2}$ Maintenance work, on the other hand, need not require secondary schooling, but can typically not relocate because proximity to the maintained facilities is required. Several important task characterizations have been proposed as relevant for their offshorability: the prevalence of codifiable rather than tacit information to perform the job (Leamer and Storper 2001); the prevalence of routine tasks, especially if they can be summarized in deductive rules (Levy and Murnane 2004); or the job's lacking requirement of physical contact and geographic proximity (Blinder 2006). Whereas the nature of tasks could be strongly correlated with the skill-intensity of the occupation, there is no a priori reason for this to be the case.

To examine the relationship between offshoring and the composition of skills and tasks in the home economy, we use plant-level data for multinational enterprises (MNEs) and information on their offshore employment. MNEs are behind an important part of worldwide offshoring. ${ }^{3}$ We combine data on German MNEs from various sources over the period 19982001, during which German MNEs greatly expanded their foreign operations. ${ }^{4}$ The data limit our analysis to offshoring within the same firm, in contrast to offshoring to independent suppliers. But a major advantage of MNE data is the possibility to relate the onshore

\footnotetext{
${ }^{1}$ See also the treatments in Baldwin and Robert-Nicoud (2007) and Kohler (2008).

${ }^{2}$ This business practice has become known as tele-radiology and, for the United States and Europe, is typically performed by U.S. or EU trained doctors living in South Asia or Australia.

${ }^{3}$ The estimated share of value added at MNE affiliates in world output was 10.1 percent in 2005, up from 6.7 percent in 1990 (UNCTAD 2006). Intra-firm trade accounts for around one-third of goods exports from Japan and the United States, a similar proportion of all U.S. goods imports, and one-quarter of all Japanese goods imports (OECD 2002).

${ }^{4}$ Some variables in our data extend to the period 1996-2006, but for the econometric analysis we use only the 1998-2001 period.
} 
workforce composition to offshore employment changes. This allows us to quantify the degree to which foreign MNE employment changes are associated with the onshore use of tasks and skills. Our firm-level information provides evidence on the responsiveness of onshore tasks to offshore employment and thereby complements the evidence on the offshorability or tradability of jobs (Jensen and Kletzer forthcoming, Blinder 2009). Our MNE data include plants from services and manufacturing so that our comparison across sectors can add to the evidence on services offshoring in Amiti and Wei (2006). Offshoring within firms is essentially defined in the same way as vertical foreign direct investment (FDI). We make no formal distinction between horizontal or vertical FDI, but the data provide information on the location of offshore activity, which we group into low-income and high-income regions, so that we can assess foreign employment changes that are potentially motivated by cost differentials to different degrees. It should also be noted that horizontal FDI seems to make up the main part of the MNEs' foreign activities (Carr, Markusen and Maskus 2001). To assess its relationship with the composition of the onshore workforce is therefore important to get the full picture of how the activities of MNEs relate to the composition of tasks and skills in the domestic plants.

We combine the detailed occupational information in our MNE plant data with survey information on task components by occupation. We follow Autor, Levy and Murnane (2003), and related research by Spitz-Oener (2006), in that we link occupations to the involved share of routine versus non-routine tasks. In addition, we link occupations to the importance of personal interaction with co-workers. To classify tasks according to the routine/non-routine and non-interactive/interactive dichotomies, we codify information from a German work survey on workplace tool use. ${ }^{5}$ We then use the survey's information on workplace tool use by occupation to map our task content measures into occupations. The prevalence of nonroutine tasks in an occupation typically relates to a lack of deductive rules and codifiable information, while the prevalence of interactive tasks relates to the potential importance of physical contact and geographic proximity. We then subject the hypothesis that routine tasks and non-interactive tasks are more offshorable to empirical tests using our MNE data.

We adopt dichotomous definitions of tasks (routine/non-routine and non-interactive/interactive), occupations (white-collar/blue-collar) and worker skills (high education/low education) throughout the analysis so that we can collapse the relative demand for onshore labor into a single reduced-form equation. This makes our empirical strategy closely comparable to cost function estimation in related work on MNEs (Slaughter 2000, Hanson, Mataloni and Slaughter 2005, Harrison and McMillan 2006). We estimate the share equation for the composition of tasks as well as our measures of skills. The task-based measures have a statistically significant relationship to offshoring in the direction theory leads us to expect: parent-firm workers perform more non-routine and more interactive tasks at MNEs with more offshoring. But the predicted economic effect of offshoring on the task composition is relatively small. We also find that offshoring is consistently associated with educational upgrading at the German plants. This is the case even when we control for the changing composition of tasks at the plant level. Somewhat surprisingly, the results for the task and

\footnotetext{
${ }^{5}$ For earlier studies on the German work survey by BIBB/IAB see, for instance, Acemoglu and Pischke (1998) or Spitz-Oener (2006).
} 
educational composition are, if anything, stronger for offshoring to high-income countries than for offshoring to low-income countries.

Our findings are consistent with the traditional view that offshored tasks tend to be carried out by low-skilled rather than high-skilled workers. The predicted economic effect of offshoring on the educational composition of onshore workforces at MNEs is however modest. Our estimates translate into a contribution of offshoring to changes in the wage-bill share of workers with at least upper-secondary education in the order of 10-15 percent-a moderate effect compared to the 15-40 percent contribution of offshoring measured as imports of intermediate inputs to the change in the wage-bill share of non-production workers in the United States (Feenstra and Hanson 1999).

Several interpretations are consistent with our finding that in-house offshoring predicts only a small recomposition towards non-routine and interactive tasks and only a small shift in onshore demand towards highly educated workers. Large workforce recompositions may take place in response to offshoring cost shocks that induce national firms to become MNEs while subsequent reductions in offshoring costs have only small effects on the workforce composition. Another possible reason for small predicted shifts is that we base estimates on the wage-bill variation within plants over time, conditioning on plant-fixed and time effects. Time indicators are highly significant predictors of the workforce composition, however, and suggest that common shocks across firms are important elements of workforce changes. It remains an open question beyond our identification strategy whether the time-varying effects are mostly related to technical change, to management practices, to offshoring, or a combination of these and other factors.

The paper has five more sections. In Section 2, we review the literature on offshoring and its implications for empirical labor-demand relationships. We lay out our estimation strategy in Section 3. Section 4 introduces our data and offers descriptive statistics. Section 5 presents the results and discusses interpretations. Section 6 concludes.

\section{Offshoring and Onshore Labor Demand}

\section{$2.1 \quad$ Related literature}

There are several models of offshoring. Early models include Jones and Kierzkowski (1990) and Feenstra and Hanson (1996), and more recent contributions are Kohler (2004), Grossman and Rossi-Hansberg (2008) and Baldwin and Robert-Nicoud (2007). A common feature of most offshoring models is that offshoring reduces production costs for offshoring firms, thereby creating general equilibrium effects similar to technological progress. ${ }^{6}$ Somewhat surprisingly, the factor benefiting the most from offshoring may be the one whose services are being offshored. This was pointed out by Jones and Kierzkowski (1990) in a setting where offshoring occurs in one sector and shown by Grossman and Rossi-Hansberg (2008) in a model of a two-sector economy with two skill groups. Absent any changes in relative goods prices, the effect on relative wages between skilled and unskilled workers depends crucially on

\footnotetext{
${ }^{6}$ For insightful reviews of this effect, see Baldwin and Robert-Nicoud (2007) and Kohler (2008).
} 
the sector bias of the cost savings generated by offshoring. ${ }^{7}$ For relatively balanced offshoring across sectors, both skilled and unskilled workers are likely to benefit from rising real wages.

The Grossman and Rossi-Hansberg (2008) model explicitly treats offshoring as trade in tasks, rather than as trade in intermediate inputs, and offers a unified framework to separate several mechanisms whereby offshoring can affect relative labor demand and relative wages. The authors emphasize a so-called productivity effect, which benefits the factor whose tasks are offshored. ${ }^{8}$ However, the model also gives rise to a standard Stolper-Samuelson effect and a labor reallocation effect related to the freeing-up of workers who have to shift to jobs with tasks that remain onshore. These two effects tend to work to the disadvantage of the factor whose tasks are being offshored. There are thus counteracting effects of offshoring on relative wages. Grossman and Rossi-Hansberg (2008) show that the larger the range of tasks already offshored, the more likely it is that the factor whose tasks are being offshored benefits. ${ }^{9}$

Few papers to date have studied the empirical nature of offshorable tasks and the extent to which offshored tasks involve high-skilled or low-skilled labor. ${ }^{10}$ Blinder (2009) uses occupational codes to construct indexes based on the binary criteria whether work can be carried out remotely or whether the job must be performed on site. According to these indexes, around a quarter of U.S. jobs are potentially offshorable. Blinder finds little or no correlation between an occupation's offshorability and the skill level of workers. For services jobs, Jensen and Kletzer (forthcoming) construct two arguably less subjective measures of offshorability. The first measure is based on the geographic concentration of industries and occupations within the United States and motivated by the idea that tradable activities are localized in few places and then traded both nationally and internationally. ${ }^{11}$ The second one is based on the occupational requirements classification of work activities in the occupational network database, from which Jensen and Kletzer pick eleven job-content measures to construct an index of offshorability. Jensen and Kletzer document that their two measures are positively correlated and find that occupations with a greater share of college-educated workers are more offshorable.

In a related line of recent research, several studies investigate the effect of technological change on relative skill demand with an emphasis on the tasks' substitutability with informa-

\footnotetext{
${ }^{7}$ Baldwin and Robert-Nicoud (2007) present necessary and sufficient conditions for changes in factor prices based on a two-factor, two-sector model.

${ }^{8}$ The effect is akin to factor-augmenting technical progress by reducing the costs of performing tasks in which a certain factor specializes. Suppose this factor is low-skilled labor and that offshoring increases as a consequence of a reduction in offshoring costs. The cost-saving induced by offshoring will then be larger in the industry using low-skilled labor intensively, inducing a reallocation of resources towards that industry. This reallocation will be associated with an increase in the relative price of low-skilled labor.

${ }^{9}$ The reason is that the magnitude of the cost-saving effect from a reduction in offshoring costs increases with the extent to which tasks are already offshored. The cost-saving effect accrues not only to the marginal task, which was previously carried out at home, but also to all inframarginal tasks that already had been offshored.

${ }^{10}$ Mankiw and Swagel (2006) survey the broader empirical literature on offshore outsourcing and U.S. MNEs and conclude that the present extent of outsourcing in the United States has at most modest labor market consequences.

${ }^{11}$ Jensen and Kletzer (forthcoming) adjust the earlier Jensen and Kletzer (2006) concentration measure for downstream demand concentration.
} 
tion technology. Autor et al. (2003) develop a framework for the changing task composition of occupations and classify tasks into five skill-related categories: routine cognitive tasks, routine manual tasks, nonroutine analytical tasks, nonroutine interactive tasks, and nonroutine manual tasks. ${ }^{12}$ They posit that computer use substitutes for cognitive and manual tasks that follow explicit rules, but that computer use complements nonroutine problem-solving and complex communications tasks. Translating task shifts into demand for education, they estimate that their model can explain more than half of the estimated relative demand shift favoring college-educated workers. For European countries, Manning, Goos and Salomons (2009) construct measures for abstract tasks, routine tasks and service tasks and use counts of news reports about offshoring of European jobs to create a proxy variable for the offshorability of occupations. They find that abstract tasks are associated with an increase in wage polarization, whereas routine tasks are associated with a decrease in wage polarization. The offshorability of occupations exhibits no statistically detectable association.

In industrialized countries, offshoring is typically expected to increase the relative demand for skilled labor. Feenstra and Hanson (1999) estimate that offshoring of intermediate input production by U.S. industries can explain 15 to 40 percent of the increase in the wagebill share of non-production workers. ${ }^{13}$ Despite the importance of MNEs for world trade, studies on MNEs report small or statistically insignificant effects of affiliate activities on the relative demand for skills in the parent firms. Using industry data for U.S. manufacturing MNEs, Slaughter (2000) finds that the industry's share of foreign affiliate production had no clear effect on the relative demand for non-production workers. Using data for Japanese manufacturing MNEs, Head and Ries (2002) conduct a similar analysis at the firm level and find a statistically significant effect of foreign affiliate employment on the wage-bill share of non-production workers at Japanese parent firms. Yet increased offshore employment explains less than ten percent of the observed change in the Japanese parents' wage-bill shares.

One possible explanation for these small effects is that a large part of the offshore activities relate to horizontal rather than vertical FDI. Horizontal FDI is motivated by improved product-market access rather than the use of lower-cost inputs as under vertical FDI (Carr et al. 2001). Horizontal FDI is likely to result in operations with similar skill intensities abroad as at the parent firm and may therefore have only small effects on the relative demand for skills at the parent. Hansson (2005) presents results lending some support to this view. Using data on Swedish manufacturing MNEs and measuring skills by educational attainment, he finds a statistically significant effect of offshoring to non-OECD countries on the wage-bill share of workers with post-secondary education, but no effect of offshoring to OECD countries. ${ }^{14}$

\footnotetext{
${ }^{12}$ Spitz-Oener (2006) applies these five categories to data for Germany.

${ }^{13}$ Hijzen, Görg and Hine (2005) use a similar concept of offshoring for the U.K. but education-based measures for skills.

${ }^{14}$ Hansson (2005) does not report how strongly changes in offshoring to non-OECD countries contribute to explaining changes in the wage-bill share of highly educated workers. Point estimates imply that a one percentage point increase in the share of non-OECD affiliate employment is associated with a .3 percentage point increase in the wage-bill share of workers with post-secondary education.
} 


\subsection{Offshoring and the composition of skills and tasks}

To illustrate how the offshoring of tasks might affect the skill intensity at home, we build on Grossman and Rossi-Hansberg (2008). For empirical implementation, we assume that skilled and unskilled workers (denoted $S$ and $L$ respectively) carry out skill-specific tasks, indexed by $i_{h}(h=S, L)$ with $i_{h} \in[0,1]$. Offshoring costs $\beta t\left(i_{h}\right)$ vary across tasks; they include a task-specific component $t\left(i_{h}\right)$ and a task-independent component $\beta$. Tasks are ranked so that $t\left(i_{h}\right)$ strictly increases in $i_{h}$ from least to most costly to offshore. This could mean that they are ranked from most routine or least interactive to the other extreme. For given factor prices $w_{h}$ at home and $w_{h}^{*}$ abroad $\left(w_{h}^{*}<w_{h}\right)$, a firm optimally offshores the tasks for which $\beta t\left(I_{h}\right) w_{h}^{*} \leq w_{h}$. So, for any given $\beta$, there is an optimal cutoff point $I_{h}$ at which all tasks with a lower $t$ than $t\left(I_{h}\right)$ are offshored. The cutoff is implicitly given by

$$
w_{h}=\beta t\left(I_{h}\right) w_{h}^{*}
$$

A reduction in $\beta$ leads to an increase in the range of offshored tasks by shifting the optimal cutoff point, thereby raising the average $t$ of the tasks that remain onshore. In the data, foreign employment shares differ across MNEs within the same sector. So, for empirical implementation, we will allow the task-independent component to vary by $\operatorname{MNE}\left(\beta_{k}\right)$ based on the assumption that there is an idiosyncratic element to offshoring costs. Then there is a firm-specific cutoff $\left(I_{k h}\right)$.

We can use this setup to discuss how a reduction in $\beta_{k}$ affects the skill intensity onshore in a firm that offshores. It is useful to distinguish between two effects: $(i)$ the change in skill intensity for given wages and $(i i)$ the change in skill intensity in response to a change in the relative wage of skilled workers. The former is a direct effect, whereas the latter is an indirect effect that arises in general equilibrium. Focusing on the direct effect, we measure skill-intensity by the wage-bill share of skilled workers as in the econometric analysis. Let $\theta_{k S}$ be a firm's onshore wage-bill share of skilled workers in the total onshore wage bill at given factor prices:

$$
\begin{aligned}
\theta_{k S} & \equiv \frac{\int_{I_{k S}}^{1} w_{S} a_{k S}(\cdot) f\left(i_{k S}\right) \mathrm{d} i_{k S}}{\int_{I_{k S}}^{1} w_{S} a_{k S}(\cdot) f\left(i_{k S}\right) \mathrm{d} i_{k S}+\int_{I_{k L}}^{1} w_{L} a_{k L}(\cdot) f\left(i_{k L}\right) \mathrm{d} i_{k L}} \\
& =\frac{w_{S} a_{k S}\left[1-F\left(I_{k S}\right)\right]}{w_{S} a_{k S}\left[1-F\left(I_{k S}\right)\right]+w_{L} a_{k L}\left[1-F\left(I_{k L}\right)\right]},
\end{aligned}
$$

where $w_{h}$ is the factor price, $a_{k h}(\cdot)$ is the factor input coefficient per unit of output (which depends on relative factor prices in general equilibrium), and $f\left(i_{k h}\right)$ is the frequency of task $i$ carried out by factor $h$ for every unit of output produced by firm $k$. We normalize so that $\int_{0}^{1} f\left(i_{k h}\right) \mathrm{d} i_{k h}=1$. More intuitively, each firm completes a fraction $\int_{I_{k h}}^{1} f\left(i_{k h}\right) \mathrm{d} i_{k h}=$ $1-F\left(I_{k h}\right)$ of $h$-tasks at home and an $h$-task requires $a_{k h}(\cdot)$ units of labor $h$ per unit of output. We choose this variation of the original Grossman and Rossi-Hansberg (2008) setup to allow for firm-specific task frequencies in the empirical implementation.

An increase in $I_{k S}$, that is an increase in the range of skilled tasks that are performed offshore, leads to a reduction in $\theta_{k S}$, while the opposite holds true for an increase in offshoring 
unskilled tasks $I_{k L}$. Formally, total differentiation of equation (1) with respect to $I_{k S}$ and $I_{k L}$ yields:

$$
\mathrm{d} \theta_{k S}=\Psi_{k S}\left[\frac{f\left(I_{k L}\right)}{1-F\left(I_{k L}\right)} \mathrm{d} I_{k L}-\frac{f\left(I_{k S}\right)}{1-F\left(I_{k S}\right)} \mathrm{d} I_{k S}\right]
$$

for

$$
\Psi_{k S} \equiv \frac{w_{S} a_{k S}\left[1-F\left(I_{k S}\right)\right] w_{L} a_{k L}\left[1-F\left(I_{k L}\right)\right]}{\left\{w_{S} a_{k S}\left[1-F\left(I_{k S}\right)\right]+w_{L} a_{k L}\left[1-F\left(I_{k L}\right)\right]\right\}^{2}}>0 .
$$

So for marginal changes in $I_{k S}$ and $I_{k L}$ (i.e., $I_{k S}=I_{k L}$ ), $\theta_{k S}$ increases if and only if the ratio between the share of high-skill and low-skill tasks remaining onshore is larger than the ratio between the frequency of high-skill and low-skill tasks at the margin:

$$
\frac{\left[1-F\left(I_{k S}\right)\right]}{\left[1-F\left(I_{k L}\right)\right]}>\frac{f\left(I_{k S}\right)}{f\left(I_{k L}\right)}
$$

In other words, whether the onshore wage-bill share of high-skilled workers increases depends on the relative importance of the offshored low-skill and high-skill tasks in production and on the relative size of low-skill and high-skill tasks remaining onshore.

An important implication for empirical work is that the effect of offshoring on $\theta_{k S}$ also depends on the relative size of the offshored tasks, i.e. the relative size of $d I_{k L}$ and $d I_{k S}$. In the setup, both $d I_{k L}$ and $d I_{k S}$ respond to changes in the same underlying offshoring cost parameter $\beta_{k}$. But by how much $I_{k h}$ increases in response to a drop in $\beta_{k}$ in optimum depends on how responsive the function $t\left(i_{k h}\right)$ is to $i_{k h}$ at the initial cutoff point $I_{k h}$. For example, if a firm is at a cutoff point where offshoring costs for low-skill tasks vary little while offshoring costs for high-skill tasks vary a lot, the setup implies that falling common offshoring costs result in a large change in $I_{k L}$ and a small change in $I_{k S}$. That is, in this case a fall in the common offshoring costs results in a large increase in the range of low-skill tasks moved offshore but only a small increase in the range of high-skill tasks moved offshore.

An alternative view on the workforce composition is more closely related to the nature of tasks as proposed by Leamer and Storper (2001), Levy and Murnane (2004) and Blinder (2006). Take the dichotomy of routine/non-routine tasks, for instance. Suppose there is a cutoff task $I_{k T}$, below which all tasks $i_{k h}$ are routine and above which all $i_{k h}$ are non-routine. Further suppose that offshoring costs are prohibitively high for non-routine tasks so that some but not all routine tasks are offshored for both low-skilled and high-skilled workers whereas all non-routine tasks remain onshore: $I_{k L}<I_{k T}$ and $I_{k S}<I_{k T}$. For this scenario, denote with $\theta_{k T}$ a firm's onshore wage-bill share for non-routine tasks at given factor prices:

$$
\begin{aligned}
\theta_{k T} & \equiv \frac{\int_{I_{k T}}^{1} w_{S} a_{k S}(\cdot) f\left(i_{k S}\right) \mathrm{d} i_{k S}+\int_{I_{k T}}^{1} w_{L} a_{k L}(\cdot) f\left(i_{k L}\right) \mathrm{d} i_{k L}}{\int_{I_{k S}}^{1} w_{S} a_{k S}(\cdot) f\left(i_{k S}\right) \mathrm{d} i_{k S}+\int_{I_{k L}}^{1} w_{L} a_{k L}(\cdot) f\left(i_{k L}\right) \mathrm{d} i_{k L}} \\
& =\frac{\left(w_{S} a_{k S}+w_{L} a_{k L}\right)\left[1-F\left(I_{k T}\right)\right]}{w_{S} a_{k S}\left[1-F\left(I_{k S}\right)\right]+w_{L} a_{k L}\left[1-F\left(I_{k L}\right)\right]} .
\end{aligned}
$$

Total differentiation of equation (4) with respect to $I_{k S}$ and $I_{k L}$ yields:

$$
\mathrm{d} \theta_{k T}=\Psi_{T}\left(w_{L} a_{k L} \mathrm{~d} I_{k L}+w_{S} a_{k S} \mathrm{~d} I_{k S}\right)>0
$$


for

$$
\Psi_{T} \equiv \frac{\left(w_{S} a_{k S}+w_{L} a_{k L}\right)\left[1-F\left(I_{k T}\right)\right]}{\left\{w_{S} a_{k S}\left[1-F\left(I_{k S}\right)\right]+w_{L} a_{k L}\left[1-F\left(I_{k L}\right)\right]\right\}^{2}}>0 .
$$

So, $\theta_{k T}$ responds unambiguously to an increase in offshoring. It strictly increases as offshoring costs $\beta_{k}$ drop and the cutoffs $I_{k L}$ and $I_{k S}$ shift up.

In general equilibrium, relative price changes indirectly affect the wage-bill shares $\theta_{k S}$ and $\theta_{k T}$ in addition. Changing relative product prices move relative wages $w_{S} / w_{L}$ and change the factor input coefficients $a_{k h}(\cdot)$. Suppose, for instance, that offshoring leads to a decrease in the relative price of products intensive in unskilled labor. Then the relative wage of unskilled workers decreases because of a Stolper-Samuelson effect. This will generate two counteracting effects on the wage-bill share of skilled labor; an increase related to the change in the relative wage and a decrease related to substitution of unskilled for skilled workers. The net effect depends on the underlying production function. For a Cobb-Douglas function, which implies a constant wage-bill share of skilled workers, the indirect effects on $\theta_{k S}$ would cancel each other with a net effect of zero.

This paper investigates the effects of foreign employment as a measure of offshoring on the onshore workforce composition at MNEs. Rich task, skill and occupation data allow us to analyze alternative measures of the onshore workforce composition associated with employment changes abroad. A necessary condition for task-related explanations of offshoring is that changes in task wage-bill shares $\theta_{k T}$ are associated with changes in offshoring. Our MNE data are well suited to test this and to quantify the economic importance of the association between foreign employment and the onshore task composition. The data also offer detailed insight into the relevance of task re-compositions for skill-related wage-bill shares $\theta_{k S}$. While the restriction to MNEs permits the observation of in-house offshore employment, and thus direct evidence on foreign and domestic workforce choices, our research design cannot address offshore outsourcing at MNEs and non-MNEs (but we do attempt to control for offshore outsourcing at MNEs with sector-level proxies). So some policy-relevant aspects of offshoring, such as welfare effects and consequences for the income distribution, remain beyond the reach of this study because they depend crucially on general equilibrium effects, which involve the factor-bias or sector-bias of offshoring and any resulting terms-of-trade changes.

\section{Estimation Strategy}

We follow the prior literature and consider a reduced-form equation to predict the relative demand for work type $i$ at an onshore plant $j$ of MNE $k$ with offshore employment $(O E)$ at location $\ell$ in year $t:^{15}$

$$
\theta_{i j t}=\sum_{\ell} \gamma_{\ell} O E_{k \ell t}+\beta_{K} \ln \frac{K_{k t}}{Y_{k t}}+\beta_{Y} \ln Y_{j t}+\beta_{w} \ln \frac{w_{i j t}}{w_{-i j t}}+\alpha_{j}+\alpha_{t}+\varepsilon_{i j t},
$$

where $\theta_{i j t}$ is the share of work type $i$ in the total wage bill at plant $j$ (measuring either task, skill or occupation wage bills), $K_{k t} / Y_{k t}$ is the parent-level capital-output ratio at MNE $k$,

\footnotetext{
${ }^{15}$ Equation (6) is a common specification in related research (Slaughter 2000, Head and Ries 2002, Hansson 2005). Now $j$ denotes the plant and $\beta$ a regression coefficient.
} 
$Y_{j t}$ is real value added at plant $j, w_{i j t}$ is the wage of work type $i$ at plant $j, w_{-i j t}$ is the composite wage of the complementary work type not in $i, \alpha_{j}$ is a plant-specific effect, $\alpha_{t}$ is a year effect, and $\varepsilon_{i j t}$ an additive disturbance.

Equation (6) states a reduced-form relationship for relative onshore labor demand, given employment $O E$ at offshore locations, and it follows from a conventional factor-demand system under some simplifying assumptions. The specification collapses MNE $k$ 's offshore employment of any work type in individual countries into employment in more aggregate locations: $O E_{k \ell t}{ }^{16}$ In our data, foreign workers are not distinguishable by work type. Therefore, we do not treat foreign employment as simultaneous factor demands in a multiequation demand system. We instead treat offshore employment as a quasi-fixed factor at the time of the onshore workforce choice. The specification makes our skill composition results closely comparable to the existing literature (Slaughter 2000, Head and Ries 2002, Hansson 2005) and thus provides a common benchmark for our novel task composition analysis. The economic motivation for a single equation (6) is that exogenous changes in offshoring costs trigger foreign employment adjustments at a longer time horizon than decisions on onshore tasks. A plausible rationale for the MNE's sequential choice is the presence of fixed coordination costs or sunk investment costs associated with offshore activities.

The wage ratio $w_{i j t} / w_{-i j s t}$ accounts for variation in the wage-bill share $\theta_{i j t}$ that is explained by relative factor prices and restricts the own- and composite cross-wage coefficients to be equal in absolute value. ${ }^{17}$ Capital enters as a quasi-fixed factor. The capital-output ratio captures unobserved user costs of capital at the parent level and accounts for variation in $\theta_{i j t}$ due to capital deepening. The plant-specific effect conditions on unobserved time-invariant plant heterogeneity. Time dummies control for changes in the workforce composition that are common to all plants. Any terms-of-trade effects associated with trade in tasks should be subsumed in these year effects.

The coefficients of foremost interest are $\gamma_{\ell}$, which can best be interpreted as capturing differential responses of MNEs to their individual offshoring conditions beyond any generalequilibrium effects. We wish to test whether $\gamma_{\ell}$ is different from zero and to quantify its economic relevance. To do so, we assess the predicted relationship between $O E_{k \ell t}$ and the wage-bill of different work types. We focus on workforce characteristics capturing the nature of tasks as well as the degree of skills. Regarding tasks we distinguish between non-routine and interactive tasks $(i)$, on the one hand, and routine or non-interactive ones $(-i)$, on the other. Regarding skills, we distinguish between workers with at least upper-secondary schooling $(i)$ and workers with less schooling $(-i)$. For comparison, we also consider the composition of white-collar $(i)$ and blue-collar $(-i)$ workers, since this dichotomy has been a widely used in the previous literature to proxy for skills.

A cause of concern is that simultaneity problems may affect equation (6). If offshore employment at $\ell$ and onshore demand for work type $i$ are simultaneously determined, then $\gamma_{\ell}$ may be biased. Instrumenting for $O E$ would help us assess this problem if a valid and strong instrument for offshore employment could be found. We report estimation results

\footnotetext{
${ }^{16}$ This strategy is similar to Hansson (2005). An alternative specification would be to interact the $O E$ measure with the per-capita income of the host country (see Head and Ries (2002) for a discussion).

${ }^{17}$ This is tantamount to assuming the short-run cost function for onshore activities to be linearly homogenous in the wages of the different work types entering the cost function.
} 
from using the two-year lag of $O E$ as instrument. The idea for the use of the two-year lag of $O E$ is inspired by the approach in Blundell and Bond (2000) who use lagged factor inputs as instruments for present factor inputs to estimate production functions. ${ }^{18}$ Our instruments are valid if current onshore employment is not related to past offshore employment other than through current offshore employment itself, conditional on other MNE-level performance variables in equation (6). While we consider this assumption plausible for the operation of MNEs, we do not want to overly stress the results from these estimations. Much of the emphasis is on the predicted relationship between offshore employment and the onshore workforce composition and we largely interpret this relationship as an informative correlation for theory and further empirical work rather than as a causal one.

A second source of potential bias arises from the presence of the log wage ratio $\ln \left(w_{i t} / w_{-i t}\right)$ because wages also enter the dependent wage-bill share variable. In a baseline specification we follow Slaughter (2000) and Head and Ries (2002), who omit $\ln \left(w_{i t} / w_{-i t}\right)$. To check robustness, we also include the relative wage term and find other coefficient estimates to remain similar. Industry-wide wages are the outcome of collective bargaining in Germany so that our use of plant data mitigates the concern that the joint determination of plant employment and wages affects estimates. We also run regressions with employment shares rather than wage-bill shares as left-hand side variables.

We estimate several variants of specification (6) to assess robustness. We use the ratio between imported intermediates and output at the industry level to control for offshore outsourcing to independent suppliers abroad. We include product-market import penetration to remove potentially spurious correlations with foreign competition and we control for R\&D intensity to proxy for technical change. Furthermore, we use the industry-specific average wage-bill share of work type $i$ in plants of non-MNEs in order to control for common trends in wage-bill shares that affect all firms within an industry. This variable also addresses concerns about changes in the supply of highly educated workers, which could lead to a coincidentally increasing proportion of highly educated workers unrelated to offshoring.

There may be important differences in the response to changing offshoring costs depending on whether it leads the firm to become an MNE or simply expand existing foreign operations. Muendler and Becker (2006) document that responses at the extensive margin accounts for about half of German MNEs' total response in terms of employment levels to wage differentials between Germany and foreign locations. We have conducted robustness checks on the relevance of selection into first-time MNE status but find the coefficient estimates for offshore employment are not affected in any substantive way. This finding is consistent with the interpretation that selection matters less for the composition than for the level of parent employment.

When estimating equation (6) for the wage-bill share of highly educated workers we also control directly for the task composition at the level of the plant. This allows us to assess whether shifts in task composition alone account for shifts in the workforce's educational

\footnotetext{
${ }^{18}$ Blundell and Bond (2000) estimate a GMM production function for first-differenced variables. We use a conventional ordinary least-squares approach for comparability to the existing literature on MNEs and allow for plant effects. Alternative instruments at the industry level, such as offshore employment by Swedish MNEs and exports and imports by Germany's trading partners, have not proven to be sufficiently strong instruments in our specification.
} 
profile. A statistically significant positive estimate of $\gamma_{\ell}$ in the presence of this control variable is consistent with the interpretation that offshoring is associated with educational upgrading in excess of what can be explained by changes in the task recomposition. Similarly, including the white-collar wage-bill share allows us to examine whether offshoring predicts educational upgrading in excess of what can explained by an occupational recomposition.

\section{Data and Descriptive Statistics}

Our data derive from the combination of four micro-data sources, assembled at Deutsche Bundesbank in Frankfurt. The unit of analysis in this paper is an onshore plant of a German MNE. ${ }^{19}$

\subsection{Data sources}

Onshore plant information comes from confidential quarterly social-security records of the German Federal Labor Agency (Bundesagentur für Arbeit BA), our first data source. The raw BA data are at the worker-job level and cover the universe of workers registered in the social insurance system over the years 1998-2006, representing around 80 percent of the formally employed German workforce. ${ }^{20}$ The records contain worker and job characteristics including worker age, education, occupation and the monthly wage. Wages in the German social security data are top-coded at the ceiling for old-age insurance, which is annually adjusted for nominal wage changes, but there is no censoring from below. ${ }^{21}$ We aggregate the worker-job information to the plant level and compute wage-bill shares for individual tasks, education levels and occupations by plant.

Second, confidential information on German MNEs and their offshore activities comes from the combined MIDI-USTAN database at Deutsche Bundesbank (BuBa); see Lipponer (2003) for a documentation of MIDI (MIcro database Direct Investment, formerly DIREK) and Deutsche Bundesbank (1998) for a documentation of USTAN (which reports parent-level operations of German MNEs). This data source offers affiliate information for 1998-2005 and parent information for 1998-2001, which means that our estimation sample becomes restricted to the period 1998-2001. The outward FDI data cover all offshore affiliates of

\footnotetext{
${ }^{19} \mathrm{~A}$ German MNE is a firm, headquartered in Germany, with reported outward FDI, or a German firm with reported outward FDI, whose ultimate beneficial owner is headquartered elsewhere. A similar data combination was performed at the worker level for the analysis in Becker and Muendler (2008).

${ }^{20}$ Covered are full- and part-time workers at private enterprises, apprentices, and other trainees, as well as temporarily suspended employment relationships. Civil servants, student workers, and self-employed individuals are excluded and make up the remaining 20 percent of the formal-sector labor force. Plants within the same municipality may report workforce information using a single plant identifier. Although our data derive from the pristine BA source, Bender, Haas and Klose's (2000) description of a random sample also applies to our universal BA records.

${ }^{21}$ We use the average monthly wage during the second quarter, when records are considered most representative for the year. Top-coding is binding only for a minor fraction of workers (Bender et al. 2000). Workers with an annual income below 3,865 EUR (in 2001) are not subject to social security contributions, but are part of our estimation sample.
} 
German MNEs according to minimal reporting thresholds. ${ }^{22}$ For the present paper, we retain MNEs in manufacturing, services (including utilities and construction), and commerce (but exclude MNEs in agriculture and mining). We extract affiliate-level information on employment and ownership (from MIDI) and parent-level information on fixed assets and value added (from USTAN). We allocate parent-level value added to the plant according to the plant's employment share in parent employment. We deflate nominal variables to the December-31 1998 value. $^{23}$

Third, we use the commercial database MARKUs (from Verband der Vereine Creditreform) on German corporate ownership to combine the preceding two data sources. MARKUS allows us to identify all onshore affiliates of MIDI-USTAN firms, to which we then link BA plants. Multinational enterprises are also multi-firm enterprises in the home economy so that outward FDI affects workers beyond the individual FDI-reporting firm's workforce. Moreover, many German enterprises bundle the management of their offshore affiliates into legally separate firms (mostly limited liability $G m b H s$ ) for tax and liability reasons. Those bundling firms then report FDI to MIDI as required by German law. The economic impact of the reporting firm's FDI, however, goes beyond the firm's narrow legal boundary in that jobs throughout the corporate group may be affected. We consider all firms within a corporate group (an enterprise) as potential FDI firms if at least one firm in the group reports outward FDI activities. $^{24}$

The resulting matched sample allows us to discern between German plants that belong to German MNEs and plants that belong to non-MNEs. We compare descriptive statistics for MNEs and non-MNEs below and use information for the non-MNEs to control for common trends in wage-bill shares at the industry level. In Section 5, we report results from an MNE sample that excludes parent firms with offshore employment greater than 100 times their onshore employment. ${ }^{25}$ Of the plant observations, we keep balanced panels to conduct plant-fixed and random effects estimation for firms that are continuously active offshore. The resulting estimation sample contains 5,064 observations of 1,266 plants at 490 MNEs for the sample period 1998-2001. The total number of employees in 1999 in the sample is 667,760, out of which 389,201 are employees in plants belonging to manufacturing MNEs. Aggregate German employment in manufacturing MNEs in 1999 was estimated to 1,597,738 by Becker, Ekholm, Jäckle and Muendler (2005). Based on the proportion of observed employees at

\footnotetext{
${ }^{22}$ In 1999 through 2001, reporting is mandatory for all offshore affiliates with either a balance sheet total of more than EUR 5 million and at least a ten-percent ownership share of the German parent or with a balance sheet total of more than EUR 0.5 million and at least a 50-percent ownership. In 1998, reporting was mandatory for offshore affiliates with a balance sheet total of more than EUR 0.5 million and at least a twenty-percent ownership share. We keep balanced panels to prevent attrition due to reporting thresholds. Our point estimates are not sensitive to omission of year-1998 observations.

${ }^{23}$ In some specifications we use turnover to measure offshore activities. We then transform affiliate turnover over the full sample period to Euros at the exchange rate on December-31 1998.

${ }^{24}$ BA, MIDI-USTAN and MARKUS do not share common firm identifiers. We use a string-matching procedure to identify clearly identical firms and their plants (see Appendix A for a detailed description).

${ }^{25}$ Head and Ries (2002) also report the presence of MNEs with large ratios of offshore to onshore employment in the case of Japanese MNEs. A considerable number of German MNEs bundle the management of offshore activities in separate German firms. Some onshore activities of corporate MNE groups may go unlinked in our string-match procedure. We therefore exclude outliers as a matter of caution (but find the results to be relatively insensitive to their inclusion).
} 
manufacturing MNEs to total employees at manufacturing MNEs, we are thus capturing around a quarter of the domestic employment at German MNEs.

\subsection{Variable construction}

Our fourth data source is the BIBB-IAB work survey, which we use to codify the tasks involved in an occupation as non-routine or interactive. For this purpose, we reclassify workers' answers to questions in the Qualification and Career Survey for 1998/99 regarding the use of 81 workplace tools in their occupations. The German Federal Institute for Vocational Training (Bundesinstitut für Berufsbildung BIBB) and the research institute of the German Federal Labor Agency (Institut für Arbeitsmarkt- und Berufsforschung IAB) conduct the survey with a random sample of one tenth of a percent of the German labor force.

Nature of tasks. To classify tasks, we start by coding the answers to 81 yes/no questions whether a worker uses a specific workplace tool or not. The 81 workplace tools range from hand tools to machinery and diagnostic devices to computers and means of transport. We assign two different indicators to the use of any given workplace tool: $(i)$ an indicator whether use of the workplace tool implies a non-routine task (characterized by non-repetitive methods of work), and (ii) an indicator whether use of the same workplace tool implies an interactive task (characterized by frequent personal interaction with coworkers, suppliers or customers). The two classifications do not need to coincide. To us, the use of a cash register, for instance, implies routine but interactive work. To be able to assess the robustness of our estimation results to these classifications, we create two different ones. One set of indicators is based on a restrictive interpretation of what might constitute non-routine (interactive) tasks, while another set is based on a more lenient interpretation (see Appendix D).

For our main measure of tasks we map tasks to occupations in three steps. First, we use information on workplace tools in 84 ISCO88 2-digit occupations from the BIBB-IAB work survey and calculate the average number of non-routine (interactive) tasks involved in performing a given 2-digit occupation (based on our codification of responses to the 81 survey questions on workplace tools). Second, we find the maximum number of non-routine (interactive) tasks required to perform any 2-digit occupation. ${ }^{26}$ Third, we measure a given 2-digit occupation's degree of non-routine (interactive) tasks as the ratio between the average number of non-routine (interactive) tasks in the occupation and the maximum number in any occupation. We standardize by the maximum and minimum number of tasks in any occupation so that task shares vary between zero and one across occupations.

With this standardization, each occupation is assigned a number between 0 and 1 that measures its intensity in non-routine and interactive tasks. In the analysis, we treat this index as a cardinal number under the assumption that the frequency of binary responses across workers in the large-scale survey is proportional to the importance of the task for a worker on a given job. Note that even if a worker spends a small amount of time on a certain task, the task may be crucial for the value of the worker's performance. In a surgeon's

\footnotetext{
${ }^{26}$ Under our restrictive codification, the observed maximum of non-routine (interactive) tasks per $I S C O 88$ 2-digit occupation is 6.7 (3.3) - after averaging over responses by occupation. Under the more lenient codification, the maximum number of non-routine (interactive) tasks per occupation is 15.4 (7.3).
} 
work day, for instance, the actual time use of a specialized medical tool may be short, but elemental. So, the frequency of binary responses is arguably a more adequate measure of task importance than time use. To assess the robustness of our task classifications, we also use an occupation-to-task mapping created by Spitz-Oener (2006) for the study of information technology use and labor demand. Whereas our codification of tasks draws on 81 questions regarding workplace tool use, the Spitz-Oener task classification draws on a complementary set of 15 activity descriptions in the same BIBB-IAB survey (for details on the Spitz-Oener mapping see Appendix D).

Offshore activities. We follow Head and Ries (2002) in measuring a plant's exposure to its parent firm's offshore activities with the share of offshore activities in total activities: ${ }^{27}$

$$
O E_{k \ell t}=\frac{\sum_{n \in \ell} x_{n t}}{\sum_{n \in \ell} x_{n t}+\sum_{j \in k} x_{j t}},
$$

where $x_{n t}$ is the activity of MNE $k$ 's offshore affiliate $n$ in location $\ell$, and $x_{j t}$ is the activity at MNE $k$ 's onshore plant $j$. For the computation of $(7), x_{n t}$ is weighted by the parent firm's ownership share in the foreign affiliate. $O E_{k \ell t}$ is a measure of the parent firm's offshore activities and does not vary across an MNE's plants. We report results for two groups of locations $\ell$ : high-income and low-income countries. ${ }^{28}$

In this paper, we measure offshore activities $O E$ with employment since offshore employment is a natural counterpart to relative labor demand at home. Marked labor productivity differences between foreign workers and workers at home, however, may lead to a small measured sensitivity of home employment with respect to offshore employment. We therefore also use sales as an alternative measure of offshore activity. Sales may suffer from other problems, however, as they can be affected by transfer pricing. Yet we find estimation results with offshore sales to be similar to those with employment, and therefore only report results based on employment. Between 1998 and 2001, measure (7) of offshore employment at German MNEs increased by .059 across all sectors on average, translating into a 5.9 percentage point increase in the share of foreign employment in total MNE employment.

\subsection{Descriptive statistics}

We present some descriptive statistics on wage-bill shares in manufacturing and services for four definitions of advanced work types: our two new task categories of non-routine and interactive tasks, workers with at least upper-secondary schooling and white-collar workers.

\footnotetext{
${ }^{27}$ The Head and Ries measure naturally varies between zero and one. An alternative measure is the ratio between offshore and onshore activities (Slaughter 2000). For any location $\ell$, that ratio is independent of the size of the parent's operations at another location (the ratio between employment in low-income countries and onshore employment is independent of employment in high-income countries). Being an unbounded ratio, however, it can be more sensitive to outliers.

${ }^{28}$ Western Europe (EU-15 plus Norway and Switzerland), Australia, Canada, Japan, New Zealand, and the United States are defined as high-income countries; while all remaining countries are defined as low-income countries.
} 
These four variables will become the dependent variables in the econometric analysis. We compute the wage-bill share in percent to vary between zero and 100 .

We do not show separate descriptive statistics for commerce here but will include wholesale and retail plants in later comparative analysis. For task measures, we use the strict classification (results change little under the more lenient classification). Workers with uppersecondary schooling have completed a university qualifying diploma (Abitur) in the German three-tier system.

The onshore workforce composition has changed substantially at MNEs and non-MNEs over the past decade. The first column of Table 1 reports the changes of wage-bill shares for the full period from 1998 to 2006 when worker-level data are available. ${ }^{29}$ There is a considerable overall shift towards more advanced work types. Moreover, wage-bill shares of the advanced work types increase more strongly at MNEs than at non-MNEs. These increases are particularly strong for highly educated and white-collar workers and less pronounced for the measures of non-routine and interactive tasks. A comparison between manufacturing and services shows that the increases are larger at services MNEs for all advanced work types except interactive tasks.

There is not only a co-movement in wage bills over time among advanced work types. In any given year, all four measures are also positively correlated in the cross section of plants. In 2004, the highest correlation is between the wage-bill shares of non-routine tasks and workers with upper-secondary education (a correlation coefficient of .615). The wage-bill share of interactive tasks is also positively correlated with that of highly educated workers (.302). So, according to our measures, occupations with a greater share of highly educated workers appear to be less associated with routine and non-interactive tasks. In contrast with Jensen and Kletzer (forthcoming) we would thus expect these occupations to be less rather than more easily offshored.

In principle, both labor supply shocks and labor demand shocks that favor more skilled labor are consistent with the time pattern in column 1 of Table 1. A decomposition into wage and employment contributions can shed light on the likely nature of the change. Wagebill shares change both when relative wages change and when relative employment shifts. To assess the relative contribution, we decompose the observed wage-bill changes. The decomposition also shows whether relative wages and relative employment covary positively or negatively. A positive covariation would suggest that labor demand shocks dominate, whereas a negative covariation would suggest that labor supply shocks dominate.

Let $\theta_{i}$ be the wage-bill share of work type $i$. A change in $\theta_{i}$ between an initial period 0 and $t$ can be split into the components

$$
\begin{aligned}
\frac{\theta_{i t}-\theta_{i 0}}{\theta_{i 0}}=\left(\frac{L_{i t}}{L_{i 0}} \frac{w_{i t}-w_{i 0}}{w_{i 0}}\right. & \left.-\frac{L_{-i t}}{L_{-i 0}} \frac{w_{-i t}-w_{-i 0}}{w_{-i 0}}\right) \Theta_{i} \\
& +\left(\frac{L_{i t}-L_{i 0}}{L_{i 0}}-\frac{L_{-i t}-L_{-i 0}}{L_{-i 0}}\right) \Theta_{i}
\end{aligned}
$$

\footnotetext{
${ }^{29}$ Later regression analysis requires more information on the parent firm, which is only available through 2001. Occupational information on white-collar jobs was discontinued after 2004 so the figures for the wage-bill share of white-collar workers are based on the 1998-2004 period.
} 
Table 1: Decomposition of Wage-Bill Changes, 1998-2006

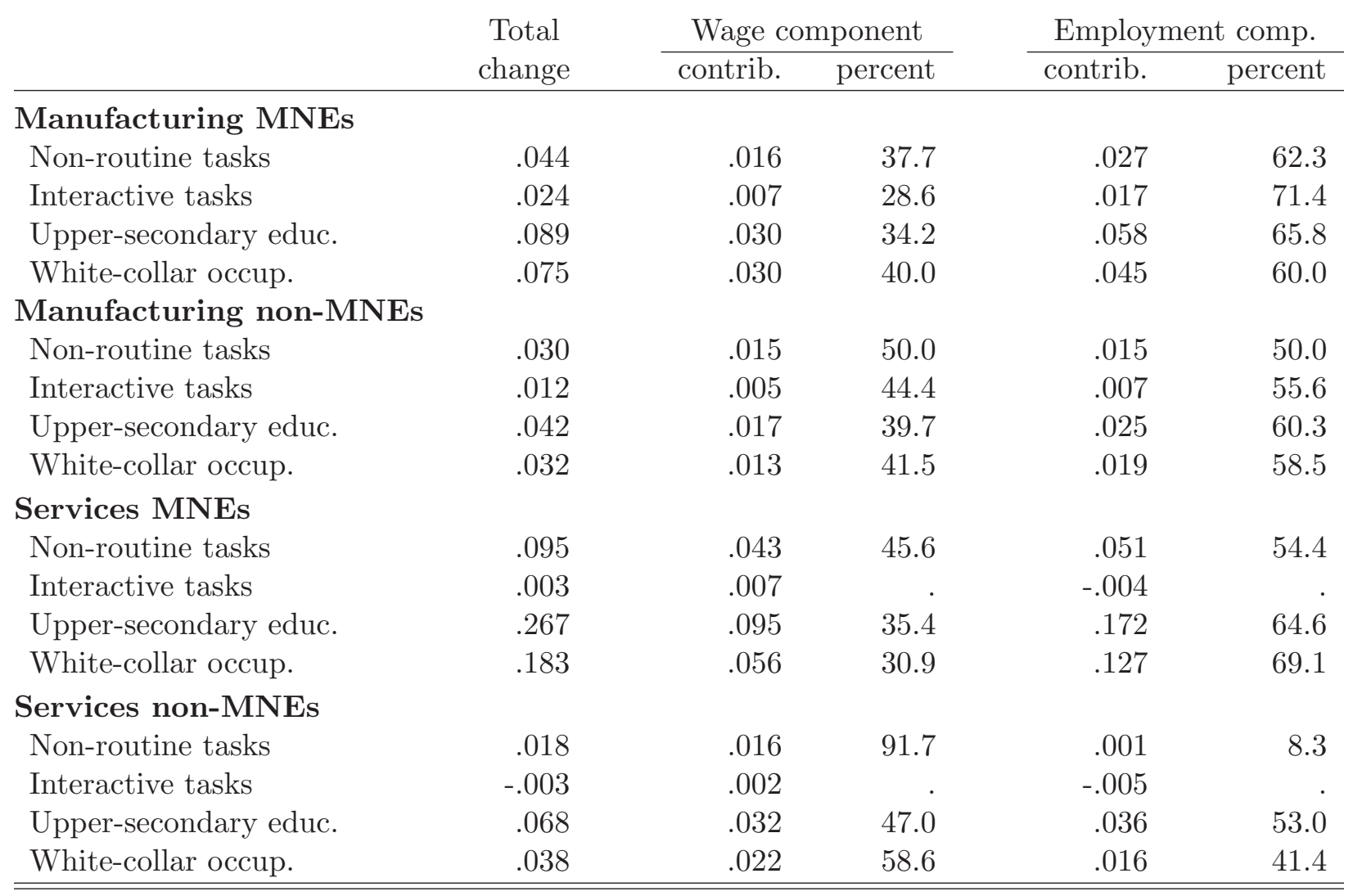

Sources: BA data 1998-2006 and BIBB-IAB worker survey 1998/99, unbalanced panel.

Note: Task measures under strict interpretation. Services exclude commerce. The decomposition of wage-bill shares for white-collar workers is based on the 1998-2004 period.

where

$$
\Theta_{i} \equiv\left(1-\theta_{i 0}\right) \frac{w_{i 0} L_{i 0}+w_{-i 0} L_{-i 0}}{w_{i t} L_{i t}+w_{-i t} L_{-i t}}
$$

and $w_{i t}$ is the wage and $L_{i t}$ the employment of work type $i$ (see Appendix $\mathrm{C}$ for a derivation). As before, the subscript $-i$ denotes the complementary work type not in $i$. We use the first term in (8) to approximate the contribution of relative wage changes and the second term to approximate the contribution of employment shifts. ${ }^{30}$

Table 1 reports this decomposition. It shows that employment shifts are for the most part the dominant contributing factor. For non-routine and interactive tasks, employment shifts at manufacturing MNEs explain around two-thirds of the wage-bill change. There are exceptions to the importance of employment shifts, however. For interactive tasks, employment shifts at services firms contribute negatively to a small increase in the wage-bill share and, for non-routine tasks at services non-MNEs, relative employment shifts contribute little to wage-bill changes. To gain some sense of the potential importance of demand and

\footnotetext{
${ }^{30}$ The first term includes weights that reflect gross employment growth and may exaggerate the relative wage contribution since most firms in our sample increase their employment over time.
} 
Table 2: Correlations Between Change in Share of Offshore Employment 1998-2001 AND WAGE-BILL Share 1998

Change in offshore employment 1998-2001

\begin{tabular}{llcc}
\cline { 2 - 4 } Initial wage-bill share & World-wide & High income & Low income \\
\hline Non-routine tasks & $.099^{* * *}$ & $.105^{* * *}$ & .037 \\
Interactive tasks & .005 & .027 & -.019 \\
Upper-secondary educated workers & $.065^{* *}$ & .027 & $.065^{* *}$ \\
White-collar occupations & -.018 & $.055^{*}$ & $-.079^{* * *}$ \\
\hline \hline
\end{tabular}

Sources: Linked BA-MIDI data 1998-2001 and BIBB-IAB worker survey 1998/99, balanced panel of MNE plants.

Note: Task measures based on restrictive interpretation (see Appendix D). Correlations from 1,246 plant observations. ${ }^{*}$ significance at ten, ${ }^{* *}$ five, ${ }^{* * *}$ one percent.

supply shifts behind the observed wage-bill changes, changes for highly educated workers are informative. For workers with upper-secondary schooling, an increase in the relative wage explains a third to a half of the increase in the wage-bill share across sectors and types of firms. The fact that both the relative wage and the employment share of workers with upper-secondary education increases is indicative of an increased relative demand for highly educated workers during the 1996-2006 period.

Offshoring is a possible candidate for explaining this increased relative demand for highly educated workers. German MNEs' offshore employment rose by 23 percent, from 3.1 to 3.8 million workers, during the same period. ${ }^{31}$ Most of this increase occurred in German services MNEs, where offshore employment rose by 48 percent, from over 1.3 to just under 2.0 million. In manufacturing MNEs, offshore employment remained roughly constant at between 1.5 and 1.6 million workers.

Table 2 presents a final piece of descriptive evidence. The table shows correlations between the change in the share of offshore employment between 1998 and 2001 and the firms' initial wage-bill shares of different work types. There are significant positive correlations between the change in offshoring to high-income countries, on the one hand, and the initial wage-bill share of non-routine tasks and white-collar workers, on the other. There is also a significant positive correlation between the change in offshoring to low-income countries and the initial wage-bill share of highly educated workers, while there is a significant negative correlation between this change and the initial wage-bill share of white-collar workers. So, offshoring to high-income countries occurred more frequently at firms with a relatively high wage-bill share of white-collar workers carrying out non-routine tasks. Offshoring to lowincome countries occurred more frequently at firms with a relatively high wage-bill share of highly educated blue-collar workers. The correlation coefficients are small, however, indicating that the association is relatively weak and offshoring appears relatively balanced across firms with different initial workforce compositions.

\footnotetext{
${ }^{31}$ We base these figures on ownership-share weighted offshore employment as in later estimation. At majority-owned foreign affiliates, employment also increased by 23 percent, from 3.0 to 3.7 million workers (unweighted employment rose by 25 percent, from 3.8 million to 4.7 million).
} 


\section{Estimation Results}

We estimate equation (6) for each of the four advanced work types: non-routine and interactive tasks, upper-secondary education and white-collar occupations.

Non-routine and interactive tasks. We start with regressions of the wage-bill shares of non-routine and interactive tasks and fit the model to all MNE-plants as well as separately to MNE-plants in manufacturing, services, and commerce. FDI in commerce primarily involves setting up sales affiliates abroad. This type of FDI might be viewed as a specific form of horizontal FDI where the firm duplicates home production abroad in order to save on trade costs. Retail and wholesale services simply cannot be delivered at a distance, implying that cross-border trade costs arguably are prohibitive for most commerce. As a consequence, one might expect offshore and onshore activities to be largely dissociated and onshore employment unaffected by offshoring in commerce. FDI in services, on the other hand, can potentially involve upstream activities that differ from those carried out at home so that cost reduction is a potentially important motive. So, FDI in services may involve both horizontal and vertical FDI, just as we also expect it to do in manufacturing.

We estimate equation (6) both for plant-fixed and plant-random effects. Results are generally similar and for the most part we focus on the results from random effects estimation. Hausman tests fail to reject exogeneity of the random effects. We take this as support for using the random-effects model, which is preferable on efficiency grounds. Furthermore, in the IV estimations of Table 6 , the magnitude of coefficients are more conservative in random-effects estimations than in fixed-effects estimation. In this section, we only present results based on the stricter classification of tasks into non-routine and interactive (Section 4, Appendix D). Table E.1 in Appendix E also presents results for the more lenient classification and the Spitz-Oener (2006) definition of non-routine and interactive tasks.

Table 3 presents results for worldwide offshoring. The first five columns show the results for non-routine tasks and the last five ones the results for interactive tasks. The two first columns for each of the task types present results for the whole sample with all sectors. The very first column is based on plant-fixed effects estimation and the second column on plant-random effects estimation. The last three columns for each task type show the results from random-effects estimations for manufacturing, services, and commerce, respectively. The point estimates for the offshoring variable show the estimated percentage-point change in the wage-bill share associated with a one unit increase in the offshoring measure, which by construction varies between zero and one (see eq. (7)).

The estimated coefficients for offshore employment in Table 3 are positive and statistically significant at the one-percent level in all regressions, except in commerce. For non-routine tasks, the estimated coefficient is somewhat higher in services than in manufacturing, but for interactive tasks the estimated coefficients are similar in magnitude across sectors. In commerce, the estimated coefficient of offshore employment is much closer to zero, which is also reflected in the fact that the estimated coefficients for the all-sector sample are smaller than the ones for manufacturing and services separately. As noted before, offshore employment increased by .059 across all sectors between 1998 and 2001. This means that the coefficient estimate in column 2 , for instance, implies a $.15(2.505 \times .059)$ percentage point increase 


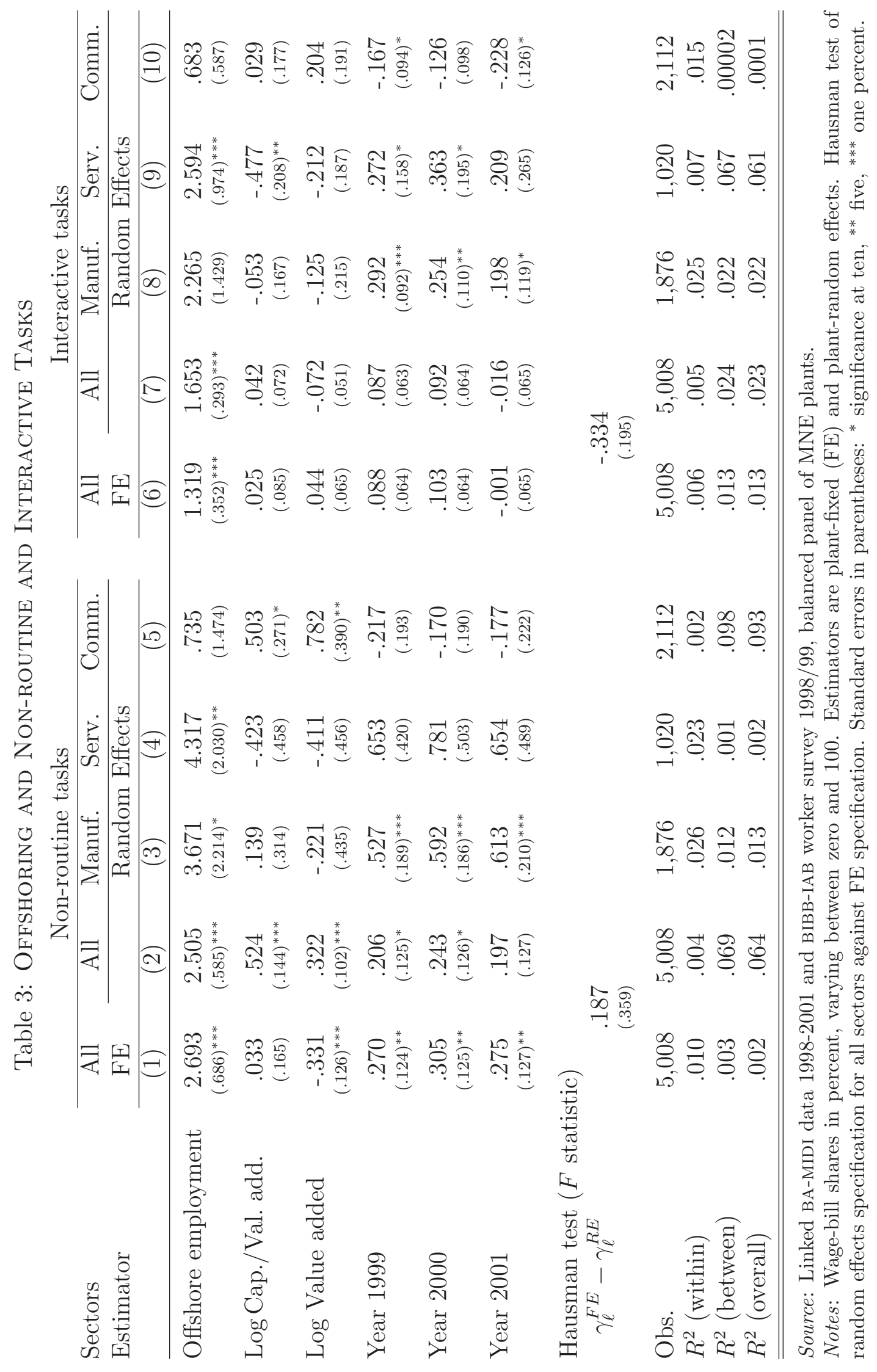


in the wage-bill share of non-routine tasks across all sectors. We will quantify the economic relevance of these and further estimates in Table 8 below.

The random-effects estimates for all sectors in Table 3 suggest that non-routine tasks are performed more frequently at MNE plants whose parent is larger in value added and more capital intensive. But neither size nor capital intensity are significantly associated with the wage-bill share of interactive tasks. While the estimated coefficients of year dummies are highly significant for the sample of manufacturing MNEs, they show no clear time pattern. We continue to control for year effects throughout, but do not report estimates subsequently for brevity. The positive association between offshoring and the wage-bill share of nonroutine and interactive tasks is robust to the choice of task classification and the inclusions of industry-level controls (see Appendix E).

The association between onshore employment and offshoring may depend on the type of location of the MNE's affiliates. Accordingly, Table 4 presents results when offshore employment is divided into offshoring to high-income (HI) and low-income countries (LI). All results are based on plant-random effects estimates. For both non-routine and interactive tasks, the estimated coefficients for offshoring to high-income and low-income countries are positive across all sectors (columns 1 and 5). The estimates are also statistically significant at the five-percent level in the all-sector sample. Remarkably, we do not find any clear evidence of a different relationship between offshoring and the wage-bill share of non-routine or interactive tasks depending on the location of offshore employment. In the case of nonroutine tasks, the estimated coefficient of offshoring to high-income countries is twice the size that of offshoring to low-income countries. If anything, this suggests that, on the margin, an increase in offshoring to high-income countries is associated with a larger increase in the wage-bill share of non-routine tasks than offshoring to low-income countries. In the case of interactive tasks, the estimated coefficients are relatively similar.

In the manufacturing (columns 2,3) and services subsamples (columns 6, 7), the offshoring measure mostly loses statistical significance for offshoring to low-income countries. The exception is a positive and significant association between the wage-bill share of interactive tasks and offshoring to low-income countries in services. Interestingly, this pattern of signs and statistical significance carries over to the association between offshoring and the onshore composition of the workforce regarding education and occupations (see Table 5 below).

As expected, there is no statistically detectable relationship between offshore employment and the onshore workforce composition in commerce. In the remainder of this section, we restrict our attention to manufacturing and services.

Education and occupations. We now turn to the results for the more conventional workforce characteristics. These are based on regressions of the onshore wage-bill share of highly educated workers and white-collar occupations on the same predictors as the ones used above. We only report the results for manufacturing and services and put the results for worldwide offshoring and offshoring to high-income and low-income countries together in 


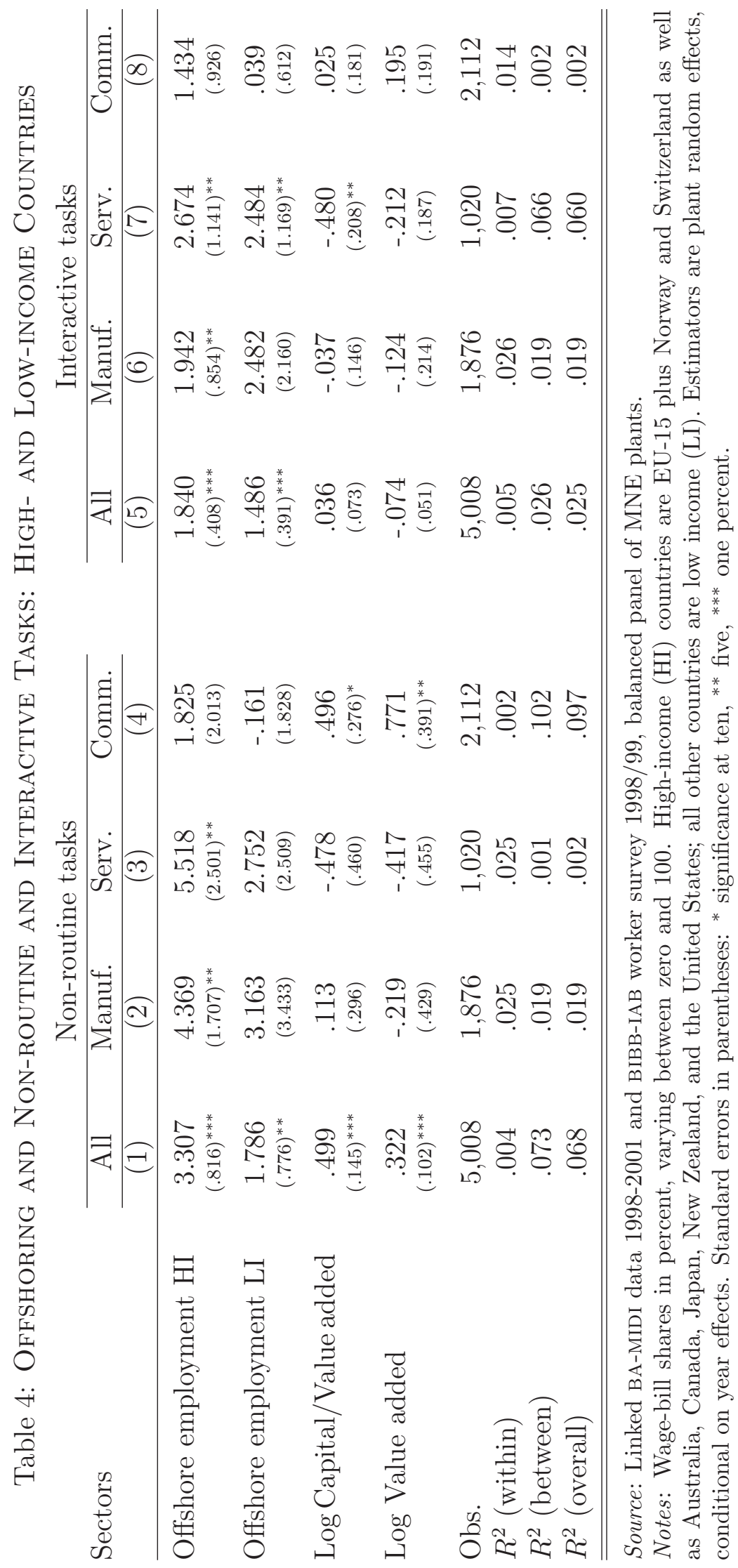




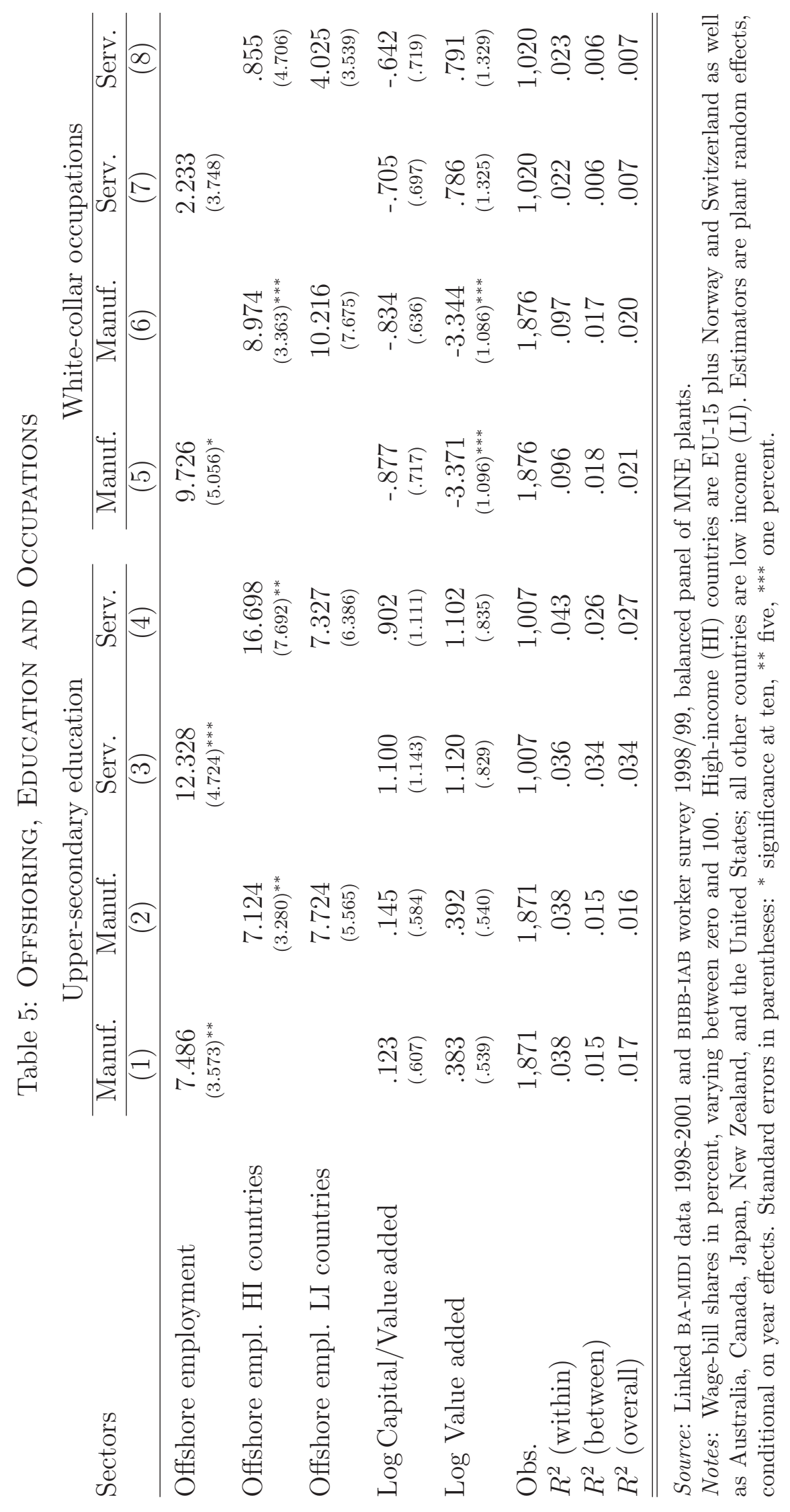


the same table (Table 5). ${ }^{32}$ The first four columns show the results for workers with uppersecondary education, while the last four ones show the results for white-collar workers.

The results for manufacturing are relatively similar across the two work types (columns 1 and 2 vis-à-vis columns 5 and 6). The estimated coefficients of worldwide offshoring as well as offshoring to high-income countries are positive and statistically significant. The point estimates are somewhat higher for white-collar workers than for the highly educated workers.

The results for services, however, differ depending on whether we measure skills by education or by the white-collar/blue-collar distinction. None of the estimated coefficients of offshoring are significant in the regressions for white-collar workers. This is not very surprising. Since most of the workers in the services sector are white-collar workers to begin with, we would not expect offshoring to be associated with a strong shift in this share. In the regressions for workers with upper-secondary education, however, the estimated coefficients for worldwide offshoring and offshoring to high-income countries are positive and significant at the five-percent level or above. As in the case of task-based measures, the estimated coefficients of offshoring to low-income countries are generally insignificant.

Instrumental variables regressions. Inspired by Blundell and Bond (2000), we use the two-year lag of offshore employment as an instrument for current offshore employment. Table 6 shows the results for all four advanced work types from two-stage least squares regressions using the all-sector sample. The lower panel reports results from the first-stage regression corresponding to the second-stage regression in the upper panel. Past offshore employment is a highly significant predictor of current offshore employment, and thus a strong instrument.

In the second stage, the estimated coefficients for worldwide offshoring (columns 1 through 4) are all positive and statistically significant, except for white-collar occupations. ${ }^{33}$ The estimated coefficients of offshoring to high-income countries are all positive and statistically significant at the five-percent level or above. As for offshoring to low-income countries, only the estimated coefficient in the regression of the wage-bill share of workers with uppersecondary education is positive and statistically significant. The others are not significantly different from zero. So, overall, the instrumental variable regressions never overturn any of our findings and confirm our earlier results when statistically significant.

Skills and tasks. So far we have shown that there seems to be a positive relationship between worldwide offshoring and the wage-bill shares of all four advanced work types and that there is no evidence that this is mainly driven by offshoring to low-income countries. Much of the debate on how offshoring may affect labor demand has centered on the question how it impacts on the relative demand for skills. As discussed in Section 2, offshoring may affect the relative demand for skills through a recomposition of tasks provided that tasks vary in skill requirement. Arguably, whether the effect of offshoring is channeled through a task

\footnotetext{
${ }^{32}$ The results for commerce and the whole sample are similar to that for the task-based measures. They are available upon request.

${ }^{33}$ In the second-stage regressions, we control for plant-random effects. Results from fixed-effect estimations are qualitatively similar, but the point estimates are larger in absolute magnitude at the same time as they have larger standard errors, rendering them statistically insignificant.
} 


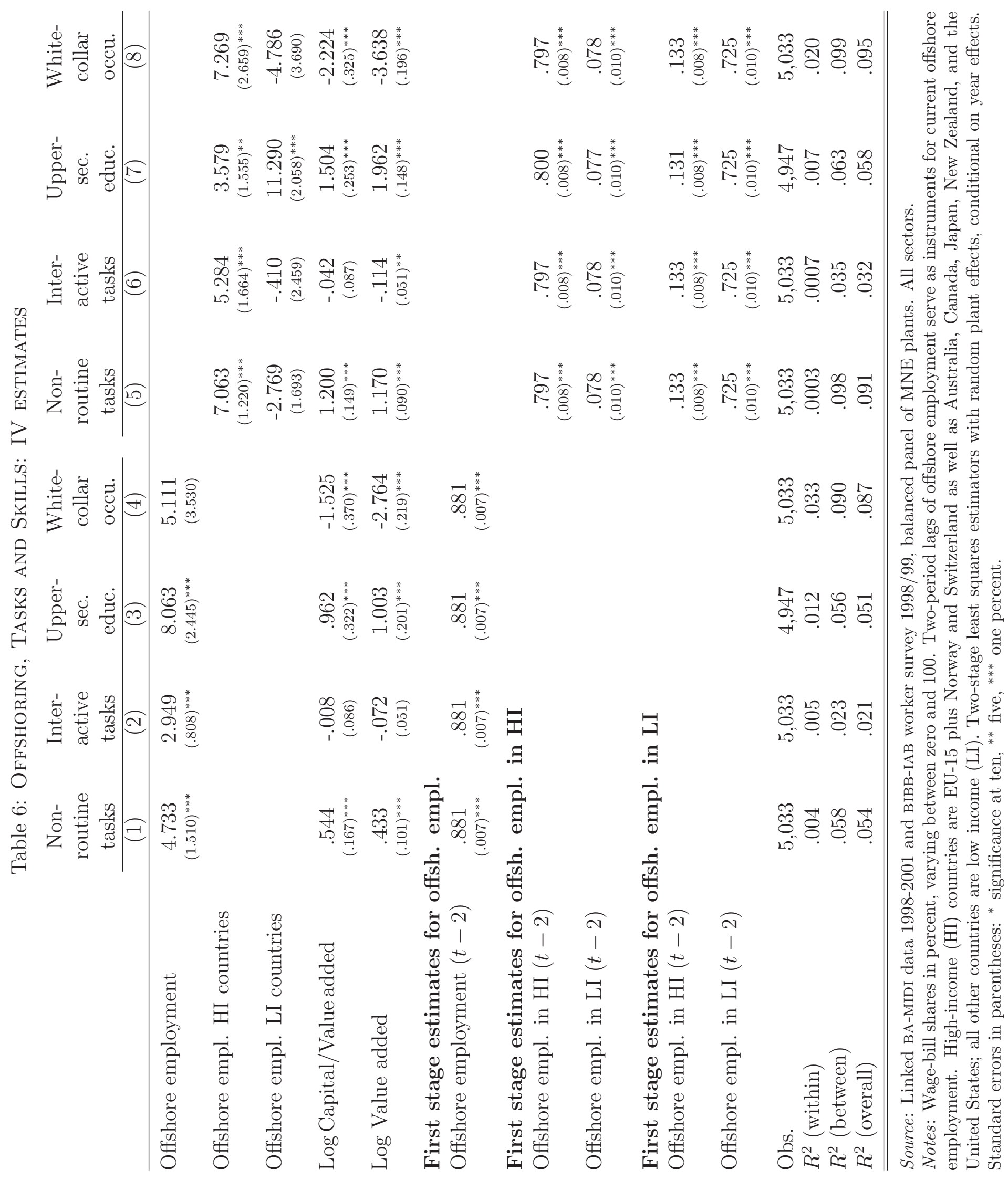


recomposition, or whether there is a direct effect on skill demand, may not matter much to the individual worker. Nevertheless, it is interesting to find out whether the association between offshoring and the composition of skills as measured by educational attainment is explained by a recomposition of tasks or whether the educational requirement seems to increase even without such recomposition. To do so we check whether the association between offshoring and the wage-bill share of workers with upper secondary education is altered when we take the task recomposition of the onshore workforce into account in the regressions.

Table 7 presents these results for the all-sector sample along with results for specifications that include industry-level controls. To facilitate comparison, the first column reports the results for a basic specification with worldwide offshoring without any additional controls. The next three columns present results from regressions that include industry-level controls similar to what have been used in earlier studies.

As explained before, our offshoring measure only captures situations where the activities located abroad remain within the firm and is in this sense more restrictive than measures based on information on imports of intermediate inputs (e.g. Feenstra and Hanson 1996, 1999, Amiti and Wei 2006). At the same time, it includes situations where the foreign activities result in production solely for the local market and is in this sense less restrictive than those measures. To check robustness of our results, we include measures of offshoring that are similar to ones used by Feenstra and Hanson $(1996,1999)$ in their studies of the impact of offshoring on the relative wage of non-production workers in the United States. They are based on information from the German input-output tables (at the NACE two-digit level). Column 2 includes narrow offshoring, which is a measure of the share of imported inputs of goods produced within the industry itself, while column 3 includes broad offshoring, which is a measure of the share of imported inputs produced across all industries. Neither of these measures are significantly related to the wage-bill share of highly educated workers, while the estimated coefficient of worldwide offshoring remains positive and statistically significant.

Column 4 includes narrow offshoring together with the industry's research intensity (R\&D per output), its import penetration (imports divided by absorption) and its overall share of workers with upper-secondary education. R\&D intensity is included to control for skilledbiased technological change while import penetration is included to control for possible effects related to increased foreign competition in the home market. The wage-bill share of workers with upper-secondary education in non-MNEs in the same industry is included to control for secular trends in the wage-bill share. As is evident from the table, none of these controls are significantly related to the wage-bill share of workers with upper-secondary education. The estimated coefficient of worldwide offshoring, however, remains significant and is only marginally smaller than in the first three columns. Overall, regressions with these industrylevel controls suggest that MNEs' onshore responses to offshoring conditions are not driven by industry-level changes.

In the last two columns of Table 7 we take on directly the question how the association between offshoring and relative onshore demand for skills is altered once the task recomposition of the onshore workforce is taken into account. In column 4 we include the employment share of non-interactive and interactive tasks and in column 5 we include the employment share of white-collar workers. In these columns, the estimated coefficient of offshoring captures the relationship between offshoring and the wage-bill share of workers with upper-secondary 


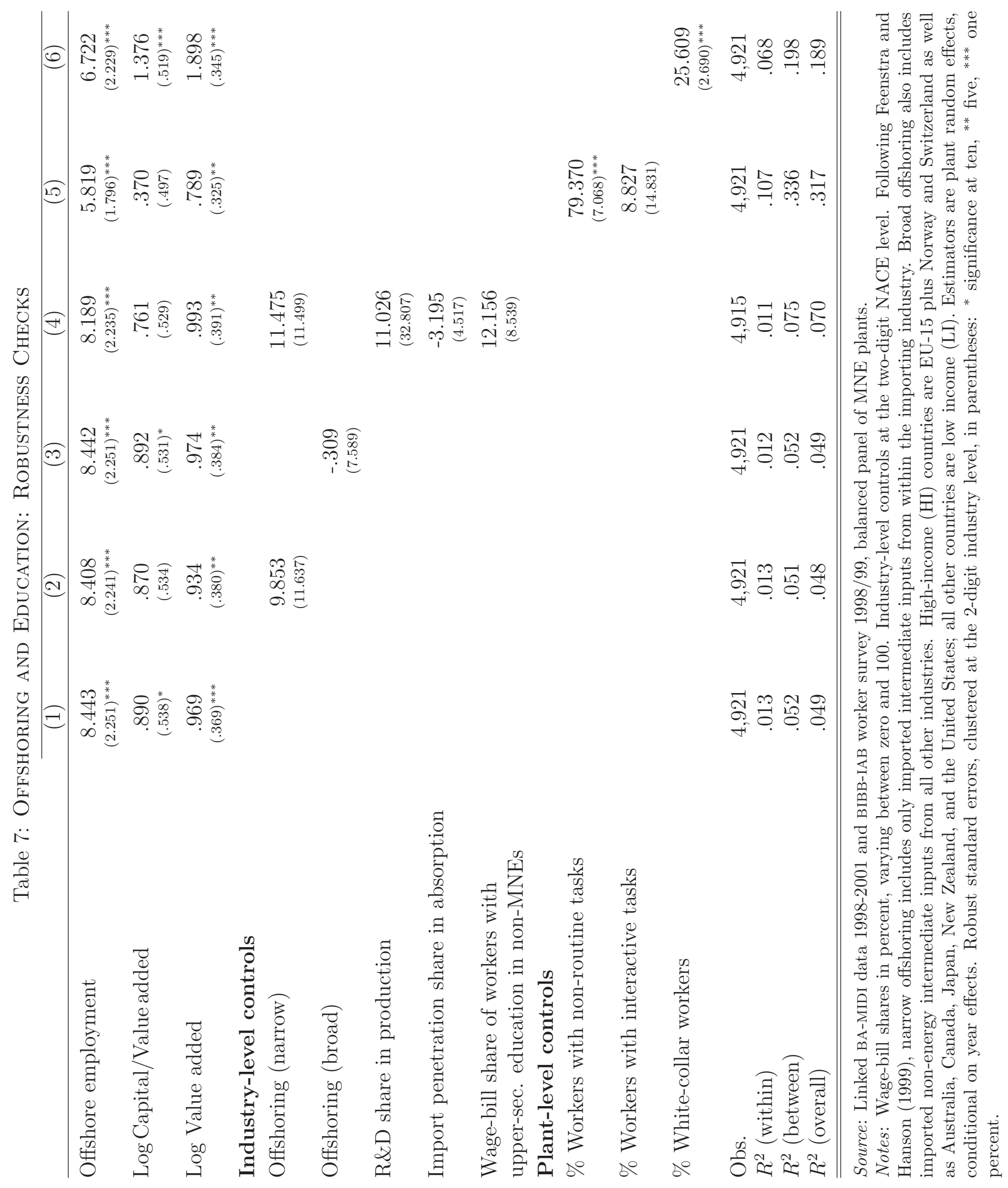


education for a given composition of tasks or occupations. The estimated coefficient is still positive and significant at the one percent level. However, the magnitude is reduced. We conclude that the wage-bill share of highly educated workers increases with offshoring in excess of what is implied by changes in the task or occupational composition. While the task and occupational composition of the onshore workforce does matter for the magnitude of the MNE's response to offshoring conditions, we thus find that it does not offer an exhaustive explanation for this response.

Sometimes offshoring is taken to mean a direct relocation of activities and might as such be defined as a situation where foreign activities expand at the same time as domestic activities shrink. In order to check whether the estimated relationship differ depending on whether the firm contracts in Germany, we have also run regressions interacting the offshoring measure with a dummy variable indicating whether employment in Germany decreases. However, the estimated coefficient of this interaction term is not significantly different from zero. Sometimes the term offshoring is used specifically to capture situations in which intermediate inputs and services are sourced from abroad, in which case it is more closely related to vertical FDI than to horizontal FDI. In order to check whether the distinction between horizontal and vertical matter for the estimated relationship we also interact the offshoring measure with an indicator whether the industry is characterized by horizontal or vertical FDI. The industry-level decomposition into vertical and horizontal FDI industries is taken from Harrison and McMillan (2006). Again, the estimated coefficients are not statistically significant. ${ }^{34}$

Throughout our regressions, time indicators are highly significant and important predictors of the workforce composition, although there is no clear time trend. Their magnitudes suggest that common shocks across firms are important, which means that the results need to be interpreted with caution. It remains for future research to discern whether the presence of these common shocks is related to offshore employment, technical change, or to a combination of these and other factors.

Economic relevance. To further assess the extent to which tasks matter for the association between offshoring and onshore employment, we quantify the explanatory power of offshore employment for wage-bill shares of the different advanced work types. More precisely, we use the offshoring coefficient estimates (from Tables 3 and 5) and the observed changes in offshoring employment between 1998 and 2001 to perform in-sample predictions of the implied changes in wage-bill shares. Table 8 presents estimates of the offshoring coefficient in regressions of wage-bill shares by work type (column 1), the observed change in offshore employment (column 2), the implied wage-bill change obtained by multiplying these two numbers (column 3), the observed wage-bill change (in column 4), and, finally, the estimated contribution of the offshoring-predicted change to the observed change in wage-bill shares (column 5).

The offshoring measure explains around ten to fifteen percent of the observed shifts in onshore wage-bill shares, with some exceptions. In manufacturing, the largest contribution is found for the wage-bill share of non-routine tasks (14 percent), while the smallest is found

\footnotetext{
${ }^{34} \mathrm{All}$ of these results are available upon request.
} 
Table 8: Offrhoring Predictions of Wage Bill Shares

Coefficient Change in Pred. change Obs. change Contrib. to

estimate offsh. emp. in wage-bill sh. in wage-bill sh. obs. change

\begin{tabular}{|c|c|c|c|c|c|}
\hline \multicolumn{6}{|l|}{ All sectors } \\
\hline Non-routine tasks & 2.51 & .059 & .148 & 1.44 & $10.2 \%$ \\
\hline Interactive tasks & 1.65 & .059 & .097 & 1.03 & $9.4 \%$ \\
\hline White-collar occupations & 6.45 & .059 & .380 & 4.56 & $8.3 \%$ \\
\hline Upper-secondary education & 8.44 & .059 & .497 & 4.23 & $11.7 \%$ \\
\hline \multicolumn{6}{|l|}{ Manufacturing } \\
\hline Non-routine tasks & 3.67 & .039 & .145 & 1.03 & $14.1 \%$ \\
\hline Interactive tasks & 2.27 & .039 & .089 & .94 & $9.5 \%$ \\
\hline White-collar occupations & 9.73 & .039 & .384 & 3.44 & $11.2 \%$ \\
\hline Upper-secondary education & 7.49 & .039 & .295 & 3.08 & $9.6 \%$ \\
\hline \multicolumn{6}{|l|}{ Services } \\
\hline Non-routine tasks & 4.32 & .090 & .390 & 4.34 & $9.0 \%$ \\
\hline Interactive tasks & 2.59 & .090 & .235 & 1.37 & $17.1 \%$ \\
\hline White-collar occupations & 2.23 & .090 & .202 & 9.84 & $2.1 \%$ \\
\hline Upper-secondary education & 12.30 & .090 & 1.115 & 11.6 & $9.6 \%$ \\
\hline
\end{tabular}

Source: Linked BA-MIDI data 1998-2001 and BIBB-IAB worker survey 1998/99, balanced panel of MNE plants. Notes: Wage-bill shares in percent, varying between zero and 100. Services exclude commerce. Task measures under strict interpretation. Predictions based on coefficient estimates in Tables 3, 4, and 5, controlling for plant random effects and year effects.

for the wage-bill share of interactive tasks (9.5 percent). The predicted contribution to the observed change in the wage-bill share of white-collar workers of 11 percent is close to the contribution of around 9 percent at Japanese MNEs reported by Head and Ries (2002).

In services, the predicted contribution to the observed changes varies more than in manufacturing. The smallest contribution-2 percent-is found for the wage-bill share of white-collar workers. As noted above, the estimated coefficient of offshoring in regressions of the wage-bill share of white-collar workers is not statistically significant. The largest contribution-17 percent-is found for the wage-bill share of interactive tasks. Offshoring is thus predicted to contribute more to the shift towards interactive tasks in services than in manufacturing.

Of special interest for inference of the likely general equilibrium effects of offshoring on wages is whether increases in offshoring tend to occur in firms using a large proportion of skilled or unskilled workers. As discussed in Section 2, the effect of offshoring on relative wages depends on the sector-bias of the cost-reductions generated by offshoring. If offshoring were found to primarily occur in relatively skill-intensive firms, it would be more likely to contribute to a widening than a narrowing of the wage gap. German firms carrying out inhouse offshoring in fact tend to be considerably more skill-intensive than firms that confine their activities to Germany. In 2006, the average employment share of workers with upper secondary education was about 25 per cent in our sample of MNEs and only about 11 per cent in our sample of non-MNEs. Of course, there may be many less skill-intensive firms that offshore activities through sub-contracting, so this is no definitive evidence for a bias 
towards skill-intensive firms.

\section{Conclusions}

Using novel plant-level data for German MNEs, this paper investigates the relationship between offshore employment and the onshore workforce composition. Drawing on detailed work-survey information regarding task types, the paper examines for the first time directly the relationship between offshoring and the composition of onshore tasks, in addition to widely used skill measures.

We find a similar relationship between German MNEs' offshore employment and the wage-bill share of white-collar workers in manufacturing as has been reported in previous studies for, among others, Japanese MNEs. We find a statistically significant positive relationships between offshore employment and the wage-bill shares of non-routine and interactive tasks for manufacturing as well as services. Non-routine tasks involve non-repetitive work methods, and interactive tasks require personal interaction with co-workers or third parties. Our results thus lend support to the view that the nature of tasks is relevant for the relationship between offshoring and onshore labor demand. Offshoring is also found to be associated with educational upgrading of the onshore workforce. Our data show a positive correlation between workers' educational attainment and their jobs' requirement of non-routine and interactive tasks. This suggests that the types of tasks that are primarily offshored tend to be carried out by workers with a relatively low educational attainment. A consistent prediction is that the changed composition of tasks associated with offshoring tends to lead to educational upgrading. However, we also find that the relationship between offshoring and the wage-bill share of workers with high education goes beyond what a recomposition of tasks or occupations implies. Even when controlling for the task and occupational composition, offshoring continues to show a strong association with educational upgrading. The results on educational upgrading support the view that foreign workers mainly substitute for less skilled domestic workers.

Somewhat surprisingly, we do not find different relationships between offshoring and the wage-bill share of advanced work types depending on whether offshoring occurs in highincome or low-income countries. To some extent, this may be explained by the fact that only a subset of the firms in the sample have activities in low-income countries. We do find a difference regarding the characteristics of firms offshoring to high-income and lowincome countries, however. Offshoring to high-income countries seems to be most frequent among firms that intensely employ white-collar workers carrying out non-routine tasks, while offshoring to low-income countries seems to be most frequent at firms intensely employing blue-collar workers with a relatively high level of educational attainment. The positive correlation between offshoring to low-income countries and skill-intensity suggests that general equilibrium effects related to the sector-bias of this part of overall offshoring may mainly benefit skilled labor.

When using our estimates to calculate the contribution of offshoring to explaining observed changes in wage-bill shares of different work types we obtain numbers in the range of ten to fifteen percent, which is similar to previous evidence on offshoring and the relative 
demand for skills. In the manufacturing sector, offshoring contributes the most to explaining changes in the wage-bill share of non-routine tasks, while in services it contributes the most to explaining changes in the wage-bill share of interactive tasks. By this measure, a focus on tasks for offshoring effects seems warranted. Nevertheless, along with all previous studies trying to assess the effect of offshoring on the relative demand for different types of workers, we find that much of the variation in the wage-bill shares is explained by other factors. 


\section{Appendix}

\section{A Linked plant-MNE data}

As in Becker and Muendler (2008), we link German plants to their corporate groups and measure the plants' exposure to MNE-wide offshore employment. This requires a two-step procedure. First, we identify all MIDI firms that are in the commercial company structure database MARKUS. Departing from the MIDI firms in MARKUS, we move both down and up in the corporate hierarchy of MARKUS to select the affiliates and ultimate parents of the MIDI firms. Second, we string-match all plants in the BA worker database to the so-selected MARKUS firms for identification of all plants related to German MNEs. A German MNE is an MNE, headquartered in Germany, with reported outward FDI, or a firm in Germany, with reported outward FDI, whose ultimate parents are headquartered elsewhere. We also string-match the plants to MIDI itself for identification of all those firms that report FDI but are not part of a corporate group (German stand-alone MNEs).

We link the data based on names and addresses. By law, German plant names must include the firm name (but may by augmented with qualifiers). Before we start the stringmatching routine, we remove clearly unrelated qualifiers (such as manager names or municipalities) from plant names, and non-significance bearing components from plant and firm names (such as the legal form) in order to compute a link-quality index on the basis of highly identifying name components. Our string-matching is implemented as a Perl script and computes link-quality indices as the percentage of words that coincide between any pair of names. We take a conservative approach to avoid erroneous links. We keep two clearly separate subsets of the original data: First, plants that are perfect links to MARKUS or MIDI, i.e. plant names that agree with firm names in every single letter. Second, plants that are perfect non-links, i.e. plant names that have no single word in common with any FDI-related MARKUS or MIDI firm. We drop all plants with a link-quality index between zero and one from our sample, i.e. plants whose name partially corresponds to an FDI firm name but not perfectly so. Those plants cannot be told to be either offshore-expansion or control plants without risk of misclassification. ${ }^{35}$ The procedure leaves us with a distinct offshore-expansion group of FDI plants and a control group of non-FDI plants.

The BA plant name file is from November 2002 and contains names of plants that are no longer active so that we include exiting and entering plants. Firm names in the MARKUS database are from three vintages of data, November 2000, November 2001 and November 2002. This is to make sure that in case of name changes in one of the years 2000 through 2002, we do not miss string-matches.

Our procedure is designed to remove laterally related firms (sisters, aunts, or nieces) from the sample so that they neither enter the offshore-expansion nor the control group. Take Example 1 of Figure 1 and consider firm 201 to be the FDI-conducting (and FDI-reporting) firm in the depicted corporate group. The first step of our procedure identifies firm 201 in MARKUS and its affiliate and parent 908 and 101 but does not identify firms 202 (a sister to

${ }^{35}$ The string-matching routine runs for several weeks, checking 3.8 million plants against 65,000 German MNEs. It is infeasible to manually treat possible links with imperfect link-quality rates. 
Example 1:

No Interlocking

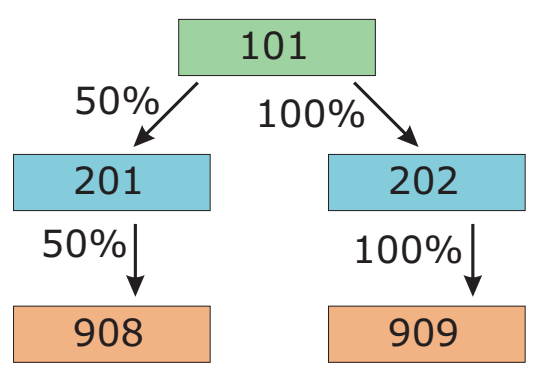

Example 2:

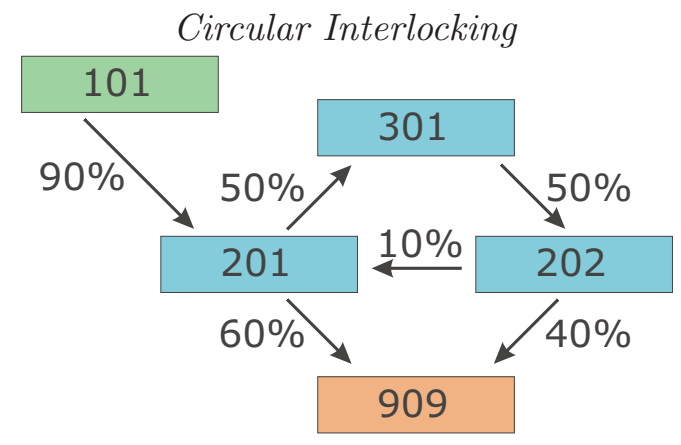

Figure 1: Examples of Corporate Groups

201) and 909 (a niece to 201). If any name component of plants in firms 202 or 909 coincides with those of 101, 201 or 908 (but the plant name is not an identical match to 101, 201 or 908), the plants in firms 202 and 909 are discarded and neither enter the offshore-expansion nor the control group. If no single name component of plants in firms 202 or 909 is the same as that of 101, 201 or 908, the plant may enter our control group. If one considers sisters, aunts, and nieces with no single identical name component to be equally affected by FDI of firm 201 as those with common names or direct relations, their inclusion in the control group would make the control group more similar to the offshore-expansion group than it should be. If anything, however, the reduced difference would work against our worker separation estimates. Moreover, interlocking (of which Example 2 of Figure 1 is a special case) limits the number of only laterally related firms.

\section{B Corporate ownership and FDI exposure}

As in Becker and Muendler (2008), we infer the economically relevant ownership share of a German firm in any other German firm. The relevant ownership share can differ from the recorded share in a firm's equity for two reasons. First, a firm may hold indirect shares in an affiliate via investments in third firms who in turn control a share of the affiliate. We call ownership shares that sum all direct and indirect shares cumulated ownership shares. Second, corporate structures may exhibit cross ownership of a firm in itself via affiliates who in turn are parents of the firm itself. We call ownership shares that remove such circular ownership relations consolidated ownership shares. This appendix describes the procedure in intuitive terms; graph-theoretic proofs are available from the authors upon request.

Consolidation removes the degree of self-ownership $(\alpha)$ from affiliates, or intermediate firms between parents and affiliates, and rescales the ultimate ownership share of the parent to account for the increased control in partly self-owning affiliates or intermediate firms (with a factor of $1 /(1-\alpha)$ ). Investors know that their share in a firm, which partly owns itself through cross ownership, in fact controls a larger part of the firm's assets and its affiliates' assets than the recorded share would indicate. In this regard, cross ownership is like selfownership. Just as stock buy-backs increase the value of the stocks because investors' de 
Table B.1: Ownership Inference

\begin{tabular}{cccccccc}
$\begin{array}{c}\text { Affiliate-parent } \\
\text { pair }\end{array}$ & \multicolumn{6}{c}{ Iteration (Length of Walk) } \\
\hline $201-101$ & .9 & .90 & .900 & .92250 & .92306 & .92308 \\
$201-202$ & .1 & & & & & \\
$201-301$ & & .05 & & .00125 & & \\
$202-101$ & & & .225 & .22500 & .23077 & .23077 \\
$202-201$ & & .25 & & .00625 & & \\
$202-301$ & .5 & & & & & \\
$301-101$ & & .45 & .450 & .46125 & .46153 & .46154 \\
$301-201$ & .5 & & & & & \\
$301-202$ & & .05 & & .00125 & & \\
$909-101$ & & .54 & .540 & .64350 & .64609 & .64615 \\
$909-201$ & .6 & & .100 & & .00006 & \\
$909-202$ & .4 & .06 & & .00150 & & \\
$909-301$ & & .20 & .030 & .00500 & .00001 & \\
\hline \hline
\end{tabular}

facto equity share rises, so do cross-ownership relations raise the de facto level of control of the parents outside the cross-ownership circle.

We are interested in ultimate parents that are not owned by other German firms, and want to infer their cumulated and consolidated ownership in all affiliates. Consider the following example of interlocking (Example 2 in Figure 1). The ultimate parent with firm ID 101 holds 90 percent in firm 201, which is also owned by firm 202 for the remaining 10 percent. However, firm 201 itself holds a 25 percent stake in firm 202-via its holdings of 50 percent of 301, which has a 50 percent stake in 201. Firms 201 and 202 hold 60 percent and 40 percent of firm 909. Our cumulation and consolidation procedure infers the ultimate ownership of 101 in all other firms.

We assemble the corporate ownership data in a three-column matrix: ${ }^{36}$ the first column takes the affiliate ID, the second column the parent ID, and the third column the effective ownership share. Table B.1 shows this matrix for Example 2 in Figure 1 (the third column with the direct ownership share is labeled 1, representing the single iteration 1).

On the basis of this ownership matrix, our inference procedure walks through the corporate labyrinth for a prescribed number of steps (or iterations). The procedure multiplies the ownership shares along the edges of the walk, and cumulates multiple walks from a given affiliate to a given ultimate parent. Say, we prescribe that the algorithm take all walks of length two between every possible affiliate-parent pair (in business terms: two firm levels up in the group's corporate hierarchy; in mathematical terms: walks from any vertex to another vertex that is two edges away in the directed graph).

We choose the following trick to infer the cumulated and consolidated ownership for ulti-

\footnotetext{
${ }^{36}$ We assemble cleared ownership data by first removing one-to-one reverse ownerships and self-ownerships in nested legal forms (such as Gmbh E Co. $K G$ ).
} 
mate parents: We assign every ultimate parent a 100 percent ownership of itself. This causes the procedure to cumulate and consolidate the effective ownership share for all affiliates of ultimate parents, at any length of walks. There are seven distinct possibilities in the example to move in two steps through the corporate labyrinth. Table B.1 lists these possibilities as iteration 2 (all entries in or below the second row). With our trick, there is now an eighth possibility to move from affiliate 201 to parent 101 in two steps because we have added the 101-101 loop with 100-percent ownership. As a result, our procedure cumulates ownerships of ultimate parents for all walks that are of length two or shorter. The procedure starts to consolidate shares as the length of the walk increases. Iteration 3 in Table B.1 shows the cumulated and partially consolidated ownership of ultimate parent 101 in affiliate 201, for all three-step walks, including the first cycle from 201 through 202 and 301 back to 201 and then to 101.

In 2000, the maximum length of direct (non-circular) walks from any firm to another firm is 21. So, for all ultimate parents, the cumulated and consolidated ownership shares are reported correctly from a sufficiently large number of iterations on. Table B.1 shows iteration 100. The ownership share of 101 in 201 has converged to the exact measure $(.9 /(1-$ $.1 \cdot .5 \cdot .5)=. \overline{923076}$ ) at five-digit precision. Firm 101 controls 92.3 percent of firm 201's assets, among them firm 201's offshore affiliates.

To calculate the FDI exposure at any hierarchy level in the corporate group, we use a single-weighting scheme with ownership shares. The economic rationale behind singleweighting is that ultimate parents are more likely to be the corporate decision units (whereas FDI conducting and reporting firms in the group may be created for tax and liability purposes). We first assign FDI exposure measures (offshore affiliate employment by world region) from onshore affiliates to their ultimate German parents. Suppose firm 201 in Example 2 of Figure 1 conducts FDI in the corporate group. We assign 92.3 percent of 201's FDI exposure to firm 101, the ultimate German parent. We then assign the same 92.3 percent of 201's FDI exposure to all affiliates of 101 (201 itself, 202, 301, 909). So, jobs throughout the group (including those at 201 itself) are only affected to the degree that the ultimate parents can control offshore-affiliate employment (or turnover). We assign only 92.3 percent of 201's FDI exposure to 201 itself because the ultimate parent only has 92.3 percent of the control over employment at $201 .^{37}$

Because we choose single-weighting in the onshore branches of the MNE, we also singleweight offshore-affiliate employment by the ownership share of the German parent in its

\footnotetext{
${ }^{37} \mathrm{An}$ alternative assignment scheme would be double-weighting, first weighting FDI exposure by ownership and then assigning the FDI exposure to jobs throughout the corporate group using ownership weights again. We decide against double-weighting. Any weighting scheme results in exposure measures that are weakly monotonically decreasing as one moves upwards in the corporate hierarchy because ownership shares are weakly less than one. Double-weighting aggravates this property. Revisit Example 1 in Figure 1 and suppose firm 201 conducts FDI. Single-weighting assigns 50 percent of 201's exposure to affiliate 908, doubleweighting only 12.5 percent. If 908 itself conducts the FDI, single-weighting assigns 25 percent of its own FDI exposure to 908 , double-weighting only 6.25 percent. In economic terms, double-weighting downplays the decision power of intermediate hierarchies in the corporate group further than single-weighting so that we favor single-weighting. Recall that purely laterally related firms (sisters, aunts and nieces) are excluded from our offshore-expansion group so that firms 202 and 909 in Example 1 of Figure 1 are not relevant for the choice of weighting scheme.
} 
offshore affiliates. Mirroring the minimal ownership threshold of 10 percent in the MIDI data on offshore affiliates, we also discard the FDI exposure of onshore affiliates with ownership shares of less than 10 percent in our single-weighting assignment of FDI exposure to onshore jobs throughout the corporate group.

\section{Wage-bill decomposition}

Consider the change in the wage-bill share of work type $i$ between 0 and $t$,

$$
\theta_{i t}-\theta_{i 0} \equiv \frac{w_{i t} L_{i t}}{W_{t}}-\frac{w_{i 0} L_{i 0}}{W_{0}}
$$

where

$$
W_{t} \equiv w_{i t} L_{i t}+w_{-i t} L_{-i t} \quad \text { and } \quad W_{0} \equiv w_{i 0} L_{i 0}+w_{-i 0} L_{-i 0} .
$$

Multiplying numerator and denominator of the first term in (C.1) with $W_{0}$ and multiplying numerator and denominator of the second term with $W_{t}$ yields

$$
\theta_{i t}-\theta_{i 0}=\frac{w_{i t} L_{i t} \cdot w_{-i 0} L_{-i 0}-w_{-i t} L_{-i t} \cdot w_{i 0} L_{i 0}}{W_{t} W_{0}}
$$

after simplifications. Multiplying and dividing the first term in (C.2) by $w_{i 0} L_{i 0}$ and the second term by $w_{-i 0} L_{-i 0}$, we find

$$
\begin{aligned}
\theta_{i t}-\theta_{i 0} & =\theta_{i 0} \Theta_{i} \cdot\left(\frac{w_{i t} L_{i t}}{w_{i 0} L_{i 0}}-\frac{w_{-i t} L_{-i t}}{w_{-i 0} L_{-i 0}}\right) \\
& =\theta_{i 0} \Theta_{i} \cdot\left(\frac{w_{i t}-w_{i 0}}{w_{i 0}} \frac{L_{i t}}{L_{i 0}}+\frac{L_{i t}}{L_{i 0}}-\frac{w_{-i t}-w_{-i 0}}{w_{-i 0}} \frac{L_{-i t}}{L_{-i 0}}-\frac{L_{-i t}}{L_{-i 0}}\right),
\end{aligned}
$$

where

$$
\theta_{i 0} \Theta_{i} \equiv \frac{w_{i 0} L_{i 0} \cdot w_{-i 0} L_{-i 0}}{W_{t} W_{0}}=\left(1-\theta_{i 0}\right) \theta_{i t} \frac{w_{i 0} L_{i 0}}{w_{i t} L_{i t}} .
$$

Adding $L_{-i 0} / L_{-i 0}-L_{i 0} / L_{i 0}=0$ to the terms in parentheses in (C.3) yields (8) in the text.

\section{Construction of tasks measures}

Our main tasks measures build on a set of 81 questions in the BIBB-IAB work survey (Qualification and Career Survey 1998/99) regarding workplace tool use. Table D.1 lists the 81 workplace tools that are surveyed. Workers report both their occupation and whether or not they use the listed tool. We codify whether or not the use of a tool indicates that the task is non-routine (involving non-repetitive work methods) or interactive (requiring interaction with co-workers or third parties). We choose to classify the use of the workplace tools under two different interpretations: our strict interpretation judges possibly few task elements to indicate non-routine work or interactive work, and our lenient interpretation judges possibly many task elements to indicate non-routine or interactive work. Table D.1 reports our 


\section{Table D.1: Workplace Tools and Non-Routine or Interactive Tasks}

Non-routine tasks Interactive tasks

Work involving

Strict def. Lenient def. Strict def. Lenient def.

$(1)$

(2)

\section{Tools or devices}

Simple tools

Precision-mechanical, special tools

Power tools

Other devices

Soldering, welding devices

Stove, oven, furnace

Microwave oven

Machinery or plants

Hand-controlled machinery

Automatic machinery

Computer-controlled machinery

Process plants

Automatic filling plants

Production plants

Plants for power generation

Automatic warehouse systems

Other machinery, plants

$\mathrm{X}$

Instruments and diagnostic devices

Simple measuring instruments

Electronic measuring instruments

Computer-controlled diagnosis

Other measuring instruments, diagnosis

\section{Computers}

Personal or office computers

Connection to internal network

Internet, e-mail

Portable computers (laptops)

Scanner, plotter

CNC machinery

Other computers, EDP devices

Office and communication equipment

Simple writing material

Typewriter

Desktop calculator, pocket calculator

Fixed telephone

Telephone with ISDN connection

Answering machine

Mobile telephone, walkie-talkie, pager

Fax device, telecopier

Speech dictation device, microphone

Overhead projector, beamer, TV

Camera, video camera

continued

(3)

3)

.


Table D.1: Workplace Tools and Non-Routine or Interactive Tasks, Cont'D

Non-routine tasks

Interactive tasks

Strict def. Lenient def. $\quad$ Strict def. Lenient def.

Work involving

$(1) \quad(2)$

continued

Office and communication equipment

Simple writing material

Typewriter

Desktop calculator, pocket calculator

Fixed telephone

Telephone with ISDN connection

Answering machine

Mobile telephone, walkie-talkie, pager

Fax device, telecopier

Speech dictation device, microphone

Overhead projector, beamer, TV

Camera, video camera

Means of transport

Bicycle, motorcycle

Automobile, taxi

Bus

Truck, conventional truck

Trucks for hazardous good, special vehicles

Railway

Ship

Aeroplane

Simple means of transport

Tractor, agricultural machine

Excavating, road-building machine

Lifting-aids on vehicles

Forklift, lifting truck

Lifting platform, goods lift

Excavator

Crane in workshops

Erection crane

Crane vehicle

Handling system

Other vehicles, lifting means

Other tools and aids

Therapeutic aids

Musical instruments

Weapons

Surveillance camera, radar device

Fire extinguisher

Cash register

Scanner cash register, bar-code reader

Other devices, implements

continued
$\mathrm{X}$

$\mathrm{X}$

$\mathrm{x}$

$\mathrm{X}$

$\begin{array}{ll}\mathrm{X} & \mathrm{X} \\ \mathrm{x} & \mathrm{x} \\ \mathrm{x} & \mathrm{x} \\ \mathrm{x} & \mathrm{x}\end{array}$

$\mathrm{x}-\mathrm{x}$

$\mathrm{x}$

$\mathrm{x} \quad \mathrm{x}$

$\mathrm{x} \quad \mathrm{x}$

$\mathrm{x} \quad \mathrm{x}$

$\mathrm{X}$

$\mathrm{X}$
$\mathrm{X}$

$\mathrm{X}$

$\mathrm{X}$

$\mathrm{X}$

$\mathrm{x}$

$\mathrm{x}$

$\mathrm{X}$

$\mathrm{x}$

$\mathrm{X}$

$\mathrm{X}$

$\mathrm{X}$

$\mathrm{X}$

$\mathrm{X}$

$\mathrm{X}$

$\mathrm{X}$

$\mathrm{x}$

$\mathrm{X}$

$\mathrm{X}$

$\mathrm{X}$

X

x

$\mathrm{X}$

$\mathrm{X}$

$\mathrm{X}$

$\mathrm{X}$

$\mathrm{X}$

$\mathrm{X}$

$\mathrm{x}$

$\mathrm{X}$ 
Table D.1: Workplace Tools and Non-Routine or Interactive Tasks, Cont'D Non-routine tasks Interactive tasks

\begin{tabular}{lcccc} 
& Strict def. & Lenient def. & Strict def. & Lenient def. \\
\cline { 2 - 5 } & $(1)$ & $(2)$ & $(3)$ & $(4)$ \\
\hline
\end{tabular}

continued

Software use by workers with computers

Word processing program

Spreadsheet program

Graphics program

Database program

Special, scientific program

Use of other software

Computer handling by workers with computers

Program development, systems analysis $\quad x$

Device, plant, system support $\quad \mathrm{x}$

User support, training

Computer use by any worker

Professional use: personal computer

Machinery handling by workers with machinery

Operation of program-controlled machinery

Installation of program-controlled machinery

Programming of program-controlled machinery

Monitoring of program-controlled machinery

Maintenance, repairs

$\begin{array}{cc} & \mathrm{x} \\ & \mathrm{x} \\ \mathrm{x} & \mathrm{x} \\ & \mathrm{x} \\ & \mathrm{x} \\ & \mathrm{x}\end{array}$

Source: BIBB-IAB worker survey 1998/99.

Note: Authors' classification of workplace-tool use associated with non-routine or interactive tasks. The strict (lenient) interpretation considers few (many) task elements to indicate non-routine or interactive work.

codification. Based on these classifications, we compute the task intensity of occupations as described in Subsection 4.2.

As a robustness check to our classification of tasks, we reuse a classification by Spitz-Oener (2006) for information technology and labor demand. The Spitz-Oener (2006) mapping is based on a set of 15 job descriptions, also in the BIBB-IAB work survey. Table D.2 lists the job descriptions. Spitz-Oener (2006) classifies job descriptions with codes v192 and v200 as (manual) routine tasks, we take the complementary 13 job descriptions to imply non-routine tasks. Following Spitz-Oener (2006), we take job descriptions v189, v190, v194, v195, and v198 to imply interactive tasks. For the mapping from tasks to occupations, we proceed similar to our own task classifications and compute the task intensity of occupations as described in Subsection 4.2. 


\section{Table D.2: Non-Routine and Interactive Tasks By Spitz-Oener}

\begin{tabular}{llcc} 
Code & Task & non-routine & interactive \\
\hline v189 & Training, teaching, instructing & $\mathrm{x}$ & $\mathrm{x}$ \\
v190 & Consulting, informing others & $\mathrm{x}$ & $\mathrm{x}$ \\
v191 & Measuring, testing, quality controlling & $\mathrm{x}$ & \\
v192 & Surveillance, operating machinery, plants, or processes & $\mathrm{x}$ & \\
v193 & Repairing, renovating & $\mathrm{x}$ & $\mathrm{x}$ \\
v194 & Purchasing, procuring, selling & $\mathrm{x}$ & $\mathrm{x}$ \\
v195 & Organizing, planning & $\mathrm{x}$ & \\
v196 & Advertising, public relations, marketing, promoting business & $\mathrm{x}$ & \\
v197 & Information acquisition and analysis, investigations & $\mathrm{x}$ & $\mathrm{x}$ \\
v198 & Conducting negotiations & $\mathrm{x}$ & \\
v199 & Development, research & & \\
v200 & Manufacture or production of merchandize & $\mathrm{x}$ & \\
v201 & Providing for, waiting on, caring for people & $\mathrm{x}$ & \\
v223 & Practicing labor law & $\mathrm{x}$ & \\
v224 & Practicing other forms of law & & \\
\hline \hline
\end{tabular}

Source: BIBB-Іав Qualification and Career Survey 1998/1999.

Note: Classification of non-routine or interactive tasks by Spitz-Oener (2006). v189-v224 codes are variable abbreviations in the BIBB-IAB data.

\section{E Additional robustness checks}

Table E.1 presents results from re-estimating the two main specifications of Table 3 in the text for alternative task measures in the all-sector sample. Columns 1 and 2 repeat the estimates from Table 3 (columns 2 and 7) to facilitate comparisons. Columns 3 and 4 in Table E.1 show results under the lenient task definitions (Table D.1) and columns 5 and 6 report results under the complementary task definitions by Spitz-Oener (Table D.2). The magnitudes of the association between offshore employment and non-routine or interactive tasks are similar across the three different task measures, although statistical significance is somewhat weaker for both the lenient definition and the Spitz-Oener definition. A similar pattern can be observed for manufacturing and services separately (not reported).

Table E.2 presents results from estimating the relationship between offshoring and the task composition with additional controls at the sector level. Tasks are classified according to the stricter definition and the controls are similar to the ones used in Table 7. To facilitate comparison, we also include the results from regressions without the additional controls in Table 3 (Columns 2 and 7). The relationship between overall offshoring and the wage-bill shares of non-routine and interactive tasks remain positive and significant when introducing these controls. 
Table E.1: Offshoring and Tasks for Alternative Task Measures

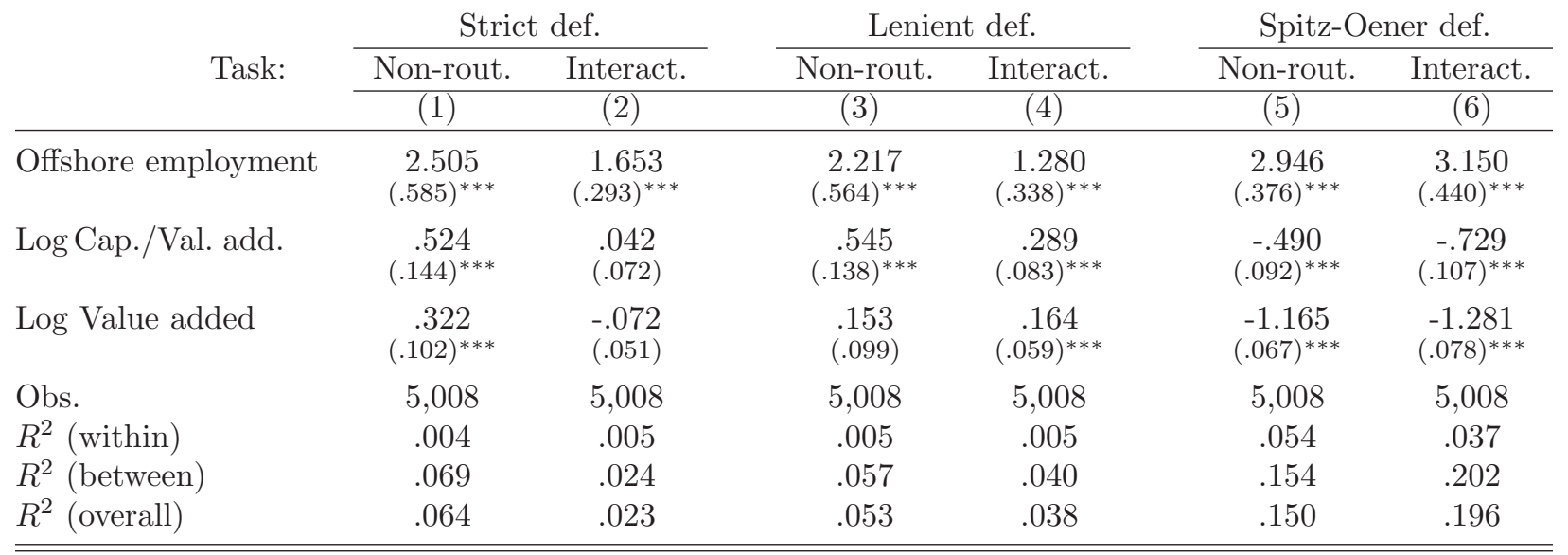

Source: Linked BA-MIDI data 1998-2001 and BIBB-IAB worker survey 1998/99, balanced panel of MNE plants.

Notes: Wage-bill shares in percent, varying between zero and 100. Estimators are plant random effects, conditional on year effects. Standard errors in parentheses: ${ }^{*}$ significance at ten, ${ }^{* *}$ five, ${ }^{* * *}$ one percent. 


\section{Table E.2: Offshoring and Tasks: Sector-Level Controls}

\begin{tabular}{|c|c|c|c|c|}
\hline & \multicolumn{2}{|c|}{ Non-routine tasks } & \multicolumn{2}{|c|}{ Interactive tasks } \\
\hline & $(1)$ & $(2)$ & $(3)$ & $(4)$ \\
\hline Offshore empl. & $\begin{array}{l}2.505 \\
(.585)^{* * *}\end{array}$ & $\begin{array}{l}2.499 \\
(.572)^{* * *}\end{array}$ & $\begin{array}{l}1.653 \\
(.293)^{* * *}\end{array}$ & $\begin{array}{l}1.706 \\
(.288)^{* * *}\end{array}$ \\
\hline Log Capital/Value added & $\begin{array}{l}.524 \\
(.144)^{* * *}\end{array}$ & .333 & $\begin{array}{l}.042 \\
(.072)\end{array}$ & $\begin{array}{l}-.007 \\
(.072)\end{array}$ \\
\hline Log Value added & $\begin{array}{l}.322 \\
(.102)^{* * *}\end{array}$ & $\begin{array}{l}.105 \\
(.102)\end{array}$ & $\begin{array}{l}-.072 \\
(.051)\end{array}$ & $\begin{array}{l}-.101 \\
(.052)^{* *}\end{array}$ \\
\hline Industry-level controls & & & & \\
\hline Offshoring (narrow) & & $\begin{array}{c}9.453 \\
(4.875)^{*}\end{array}$ & & $\begin{array}{l}3.360 \\
(2.485)\end{array}$ \\
\hline $\mathrm{R} \% \mathrm{D}$ share in production & & $\begin{array}{l}22.041 \\
(17.812)\end{array}$ & & $\begin{array}{l}33.665 \\
(8.958)^{* * *}\end{array}$ \\
\hline Import penetration share in absorption & & $\begin{array}{l}-1.496 \\
(2.036)\end{array}$ & & $\begin{array}{c}-9.078 \\
(1.027)^{* * *}\end{array}$ \\
\hline $\begin{array}{l}\text { Wage-bill share of non-routine } \\
\text { tasks in non-MNEs }\end{array}$ & & $\begin{array}{l}36.423 \\
(2.754)^{* * *}\end{array}$ & & \\
\hline $\begin{array}{l}\text { Wage-bill share of interactive } \\
\text { tasks in non-MNEs }\end{array}$ & & & & $\begin{array}{l}14.365 \\
(1.801)^{* * *}\end{array}$ \\
\hline Obs. & 5008 & 5002 & 5008 & 5002 \\
\hline$R^{2}$ (within) & .004 & .006 & .005 & .002 \\
\hline$R^{2}$ (between) & .069 & .199 & .024 & .157 \\
\hline$R^{2}$ (overall) & .064 & .197 & .023 & .149 \\
\hline
\end{tabular}

Source: Linked BA-MIDI data 1998-2001 and BIBB-IAB worker survey 1998/99, balanced panel of MNE plants.

Notes: Wage-bill shares in percent, varying between zero and 100. Estimators are plant random effects, conditional on year effects. Robust standard errors, clustered at the 2-digit industry level, in parentheses: * significance at ten, ${ }^{* *}$ five, ${ }^{* * *}$ one percent. 


\section{References}

Acemoglu, Daron and Jörn-Steffen Pischke, "Why Do Firms Train? Theory and Evidence," Quarterly Journal of Economics, February 1998, 113 (1), 79-119.

Amiti, Mary and Shang Jin Wei, "Service Offshoring and Productivity: Evidence from the United States," NBER Working Paper, 2006, 11926.

Autor, David H., Frank Levy, and Richard J. Murnane, "The Skill Content of Recent Technological Change: An Empirical Exploration," Quarterly Journal of Economics, November 2003, 118 (4), 1279-1333.

Baldwin, Richard and Frédéric Robert-Nicoud, "Offshoring: General Equilibrium Effects on Wages, Production and Trade," NBER Working Paper, March 2007, 12991.

Becker, Sascha O. and Marc-Andreas Muendler, "The Effect of FDI on Job Security," The B.E. Journal of Economic Analysis \& Policy: Advances, April 2008, 8 (1), Article 8.

_, Karolina Ekholm, Robert Jäckle, and Marc-Andreas Muendler, "Location Choice and Employment Decisions: A Comparison of German and Swedish Multinationals," Review of World Economics/Weltwirtschaftliches Archiv, December 2005, 141 (4), 693-731.

Bender, Stefan, Anette Haas, and Christoph Klose, "The IAB Employment Subsample 1975-1995," Journal of Applied Social Science Studies, 2000, 120 (4), 649-62.

Blinder, Alan, "How Many U.S. Jobs Might Be Offshorable?," World Economics, April-June 2009, 10 (2), 41-78.

Blinder, Alan S., "Offshoring: The Next Industrial Revolution?," Foreign Affairs, March-April 2006,85 (2), 113-28.

Blundell, Richard and Stephen R. Bond, "GMM Estimation with Persistent Panel Data: An Application to Production Functions," Econometric Reviews, 2000, 19 (3), 321-40.

Carr, David L., James R. Markusen, and Keith E. Maskus, "Estimating the KnowledgeCapital Model of the Multinational Enterprise," American Economic Review, June 2001, 91 (3), 693-708.

Deutsche Bundesbank, "The Methodological Basis of the Deutsche Bundesbank's Corporate Balance Sheet Statistics," Monthly Report, October 1998, 1998 (10), 49-64.

Feenstra, Robert C. and Gordon H. Hanson, "Globalization, Outsourcing, and Wage Inequality," American Economic Review: Papers and Proceedings, May 1996, 86 (2), 240-45.

_ and _, "The Impact of Outsourcing and High-Technology Capital on Wages: Estimates for the United States, 1979-1990," Quarterly Journal of Economics, August 1999, 114 (3), 907-40.

Grossman, Gene M. and Esteban Rossi-Hansberg, "Trading Tasks: A Simple Theory of Offshoring," American Economic Review, December 2008, 98 (5), 1978-97. 
Hanson, Gordon H., Raymond J. Mataloni, and Matthew J. Slaughter, "Vertical Production Networks in Multinational Firms," Review of Economics and Statistics, November 2005, $87(4), 664-78$.

Hansson, Pär, "Skill Upgrading and Production Transfer within Swedish Multinationals," Scandinavian Journal of Economics, December 2005, $10^{\text {r }}$ (4), 673-92.

Harrison, Ann E. and Margaret S. McMillan, "Outsourcing Jobs? Multinationals and U.S. Employment," NBER Working Paper, July 2006, 12372.

Head, Keith and John Ries, "Offshore Production and Skill Upgrading by Japanese Manufacturing Firms," Journal of International Economics, October 2002, 58 (1), 81-105.

Hijzen, Alexander, Holger Görg, and Robert C. Hine, "International Outsourcing and the Skill Structure of Labour Demand in the United Kingdom," Economic Journal, October 2005, 115 (506), 860-78.

Jensen, J. Bradford and Lori G. Kletzer, "Tradable Services: Understanding the Scope and Impact of Services Offshoring," in Lael Brainard and Susan M. Collins, eds., Offshoring whitecollar work, Vol. 2005 of Brookings Trade Forum, Washington, D.C.: Brookings Institution, 2006, chapter 3, pp. 75-133.

_ and _ , "Measuring Tradable Services and the Task Content of Offshorable Services Jobs," in Katharine G. Abraham, James R. Spletzer, and Michael Harper, eds., Labor in the New Economy, NBER Studies in Income and Wealth, Chicago: University of Chicago Press, forthcoming, chapter 8 .

Jones, Ronald W. and Henryk Kierzkowski, "The Role of Services in Production and International Trade: A Theoretical Framework," in Ronald W. Jones and Anne O. Krueger, eds., The political economy of international trade: Essays in honor of Robert E. Baldwin, Oxford and Cambridge, MA: Blackwell, 1990, chapter 3, pp. 31-48.

Kohler, Wilhelm, "International Outsourcing and Factor Prices with Multistage Production," Economic Journal, March 2004, 114 (494), C166-85.

_ , "Offshoring: Why Do Stories Differ?," CESifo Working Paper, February 2008, 2232.

Leamer, Edward E. and Michael Storper, "The Economic Geography of the Internet Age," Journal of International Business Studies, 4th Quarter 2001, 32 (4), 641-65.

Levy, Frank and Richard J. Murnane, The New Division of Labor, Princeton: Princeton University Press, 2004.

Lipponer, Alexander, "A "New" Micro Database for German FDI," in Heinz Herrmann and Robert Lipsey, eds., Foreign Direct Investment in the Real and Financial Sector of Industrial Countries, Berlin: Springer, 2003, pp. 215-44.

Mankiw, Gregory N. and Phillip Swagel, "The Politics and Economics of Offshore Outsourcing," Journal of Monetary Economics, July 2006, 53 (5), 1027-56. 
Manning, Alan, Maarten Goos, and Anna Salomons, "Job Polarization in Europe," American Economic Review: Papers and Proceedings, May 2009, 99 (2), forthcoming.

Markusen, James R., "Modeling the Offshoring of White-Collar Services: From Comparative Advantage to the New Theories of Trade and Foreign Direct Investment," in Lael Brainard and Susan M. Collins, eds., Offshoring white-collar work, Vol. 2005 of Brookings Trade Forum, Washington, D.C.: Brookings Institution, 2006, chapter 1, pp. 1-34.

Muendler, Marc-Andreas and Sascha O. Becker, "Margins of Multinational Labor Substitution," CESifo Working Paper, May 2006, 1713. revision and resubmission to American Economic Review.

OECD, "Intra-industry Trade and Intra-firm Trade and the Internationalisation of Production," in "Economic Outlook," Vol. 71, Paris: OECD, June 2002, chapter VI, pp. 159-170.

Slaughter, Matthew J., "Production Transfer within Multinational Enterprises and American Wages," Journal of International Economics, April 2000, 50 (2), 449-72.

Spitz-Oener, Alexandra, "Technical Change, Job Tasks, and Rising Educational Demands: Looking Outside the Wage Structure," Journal of Labor Economics, April 2006, 24 (2), 23570.

UNCTAD, World Investment Report, New York and Geneva: United Nations, 2006. FDI from Developing and Transition Economies: Implications for Development. 